\title{
ARTICLES
}

\section{AFTER THE DEAL: FANNIE, FREDDIE, AND THE FINANCIAL CRISIS AFTERMATH}

\author{
STEVEN Davidoff Solomon \& DAVID ZARING*
}

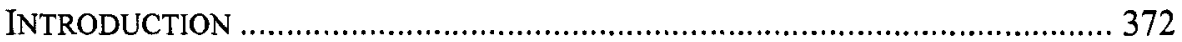

I. THE RISE AND FALL OF FANNIE AND FREDDIE ............................... 378

II. WHERE CORPORATE AND ADMINISTRATIVE LAW MEET ................... 387

A. The Corporate Law Case Against the Government ..................... 390

B. Corporate Law Meets Administrative Law ................................ 394

1. Sovereign Immunity and the Conflict of Interest Exception ...................................................................... 395

2. Arbitrariness, Unreasonableness, and the Third

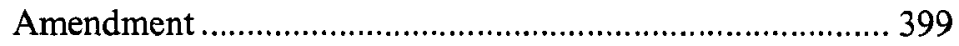

3. Issues of Remedy and Administrative Law ........................ 403

4. Constitutional Issues and the Takings Clause .......................406

III. SOLVING FANNIE AND FREDDIE ............................................... 410

A. Discipline Through the APA ................................................... 410

B. The Administrative Remedy Applied to Fannie Mae and

Freddie Mac .......................................................................... 417

IV. LESSONS FOR THE NEXT FINANCIAL CRISIS .................................... 419

A. Implications for Government Dealmaking ............................... 420

B. On the Virtues of Shareholder Activism ..................................... 422

C. A Problem of Over-Deterrence? .............................................. 423

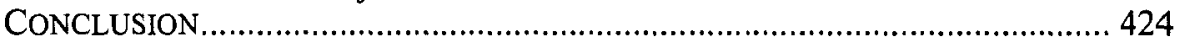

" Professor of Law, University of California, Berkeley, School of Law and Associate Professor of Legal Studies and Business Ethics, Wharton School, University of Pennsylvania, respectively. We thank Adam Badawi, Chris Brummer, Vince Buccola, John Carney, Anthony Casey, Nico Comell, Nestor Davidson, Richard Epstein, Sarah Light, Anne O'Connell, Jennifer Pacella, and Chris Serkin for their helpful comments and suggestions. Thanks also to participants at workshops at the Academy of Legal Studies in Business Annual Meeting and San Diego Law School for their feedback; Wharton's Rodney L. White Center for Financial Research for financial support; and Kevin Hoagland-Hanson and Isaac Roszler for their research assistance. 
The dramatic events of the financial crisis led the government to respond with a new form of regulation. "Regulation by deal" bent the rule of law to rescue financial institutions through transactions and forced investments; it may have helped to save the economy, but it failed to observe a laundry list of basic principles of corporate and administrative law. We examine the aftermath of this kind of regulation through the lens of the current litigation between shareholders and the government over the future of Fannie Mae and Freddie Mac. We conclude that while regulation by deal has a place in the government's financial crisis toolkit, there must come a time when the law again takes firm hold. The shareholders of Fannie Mae and Freddie Mac, who have sought damages from the government because of its decision to eliminate dividends paid by the institutions, should be entitled to review of their claims for entire fairness as part of an Administrative Procedure Act remedy-a solution that blends corporate and administrative law. Our approach will discipline the government's use of regulation by deal in future economic crises and provide some ground rules for its exercise at the end of this one-without providing activist investors, who we contend are becoming increasingly important players in regulation, with an unwarranted windfall.

\section{INTRODUCTION}

This Article is about what happens when bedrock principles of corporate governance-in particular, the fiduciary obligations that managers and controlling shareholders must observe when they deal with the other owners of the firm-conflict with government regulatory policy.

During the financial crisis, corporate governance conflicts were resolved in favor of the government and the niceties of legal rules and norms were circumvented when regulators, as they did on a number of occasions, forced transactions on tottering financial institutions, or obligated them to receive investments of funds from Treasury.

The crisis is now over, but the conflicts remain. They have come to a head most saliently over the future of the quasi-nationalized mortgage banks Fannie Mae and Freddie Mac. ${ }^{1}$ Fannie Mae and Freddie Mac shareholders, led by the generally respected, if occasionally controversial, hedge funds Perry Capital, LLC, Pershing Square Capital Management, L.P., and Fairholme Funds, Inc., but including various other institutional and individual investors, have filed lawsuits claiming that the federal government is illegally seizing the profits of the two government service entities ("GSEs"). ${ }^{2}$ Consumer advocate Ralph

1 These two entities are popularly known as Fannie Mae and Freddie Mac. Their real names are The Federal National Mortgage Association and The Federal Home Loan Mortgage Corporation, respectively.

2 See Complaint, Rafter v. United States, No. 14-cv-1404 (D.D.C. Aug. 15, 2014) [hereinafter Pershing Square Complaint]; Consolidated Amended Class Action and Derivative Complaint, In re Fannie Mae/Freddie Mac Senior Preferred Stock Purchase Agreement Class Action Litig., No. 13-mc-1288 (D.D.C. Dec. 3, 2013) [hereinafter 
Nader has begun a crusade to allow shareholders to share in Fannie and Freddie's new-found riches. ${ }^{3}$ Congress has held hearings on the matter, ${ }^{4}$ and both sides of the dispute have assembled a stellar roster of legal talent to prosecute and defend the litigation. ${ }^{5}$ Multi-billion dollar judgments have been sought, too. ${ }^{6}$

All of this makes the dispute important in its own right, as its resolution will have a real bearing on the future of housing finance in the country. ${ }^{7}$ But the

Shareholder Class Action Complaint]; Complaint, Arrowood Indem. Co. v. Fed. Nat'l Mortg. Ass'n, No. 13-cv-1439 (D.D.C. Sept. 20, 2013); Complaint, Fairholme Funds, Inc. v. Fed. Hous. Fin. Agency, No. 13-cv-1053 (D.D.C. July 10, 2013) [hereinafter Fairholme Funds Complaint]; Complaint, Perry Capital, LLC v. Lew, No. 13-cv-1025 (D.D.C. July 7, 2013) [hereinafter Perry Capital Complaint]; Complaint, Arrowood Indem. Co. v. United States, No. 13-cv-698 (Fed. Cl. Sept. 18, 2013); Verified Shareholder Derivative Complaint, Shipmon v. United States, No. 13-cv-672 (Fed. Cl. Sept. 12, 2013); Verified Shareholders Derivative Complaint, Fisher v. United States, No. 13-cv-608 (Fed. Cl. Aug. 26, 2013); Complaint, Fairholme Funds, Inc. v. United States, No. 13-cv-465 (Fed. Cl. July 9, 2013); Complaint, Wash. Fed. v. United States, No. 13-cv-385 (Fed. Cl. June 10, 2013); Class Action Complaint, Cacciapelle v. United States, No. 13-cv-466 (Fed. Cl. July 10, 2013). We refer to these cases, collectively, as the "GSE Litigation." For another example, see Cont'l W. Ins. Co. v. Fed. Hous. Fin. Agency, No. 14-cv-42 (S.D. Iowa Feb. 5, 2014).

${ }^{3}$ See Bethany McLean, Op-Ed., How Ralph Nader Learned to Love Fannie and Freddie, REUTERS (Feb. 18, 2014), http://blogs.reuters.com/bethany-mclean/2014/02/18/nader-nowgses-are-the-good-guys, archived at http://perma.cc/ZN72-R34C. Commentators on the other side of the political spectrum have also remarked on the effects of the government's policies on the GSEs' shareholders. See, e.g., William M. Isaac, Playing Semantic Games with Fannie and Freddie Investors, WALL ST. J. (July 6, 2014, 5:55 PM), http://online.wsj.com/articles/william-isaac-playing-semantic-games-with-fannie-and-

freddie-investors-1404683708 (discussing how the Obama administration's actions in court and public statements "demonstrate a profound lack of adherence to the government's duty as conservator").

${ }^{4}$ See, e.g., Fannie Mae, Freddie Mac \& FHA: Taxpayer Exposure in the Housing Markets: Hearing Before the H. Comm. on the Budget, 112th Cong. (2011).

5 The GSE Litigation includes former solicitors general Theodore Olson, partner at Gibson, Dunn \& Crutcher, counsel for Perry Capital, and Paul D. Clement, partner at Bancroft PLLC, counsel for Fannie Mae and Freddie Mac. David McAfee, Treasury, FHFA Duck Suits Over Fannie, Freddie Profit Sweep, Law360 (Sept. 30, 2014, 9:56 AM), available at http://www.law360.com/articles/582869/treasury-fhfa-duck-suits-over-fanniefreddie-profit-sweep; Theodore B. Olson, Op-Ed., Treasury's Fannie Mae Heist, WALL ST. J. (July 23, 2013, $2: 22 \quad$ PM), http://online.wsj.com/news/articles/SB10001424127887323309404578617451897504308.

${ }^{6}$ See, e.g., Nick Timiraos, Lawsuit Challenges Takeover of Fannie, Freddie, WALL ST. J. (June $10, \quad 2013, \quad 8: 12 \quad$ PM), http://online.wsj.com/news/articles/SB10001424127887323949904578537994000684874 (stating that some plaintiffs have sought $\$ 41$ billion in the litigation).

${ }^{7}$ Or so many legal and business academics have concluded. See, e.g., Adam J. Levitin \& Susan M. Wachter, Explaining the Housing Bubble, 100 GEO. L.J. 1177, 1179 (2012) ("Until we understand how and why the housing bubble occurred, we cannot be certain that 
conflict also represents a new front in the debate over how, and who should be able, to hold the government accountable for its actions during and in the aftermath of an economic emergency.

We think that these lawsuits are compelling-even if the plaintiffs are not particularly attractive-despite a few recent losses in the lower federal courts. ${ }^{8}$ The suits represent both opportunistic behavior by the funds that swooped in to purchase Fannie Mae and Freddie Mac shares after a bailout and a serious effort to identify constraints on the way the government has managed the financial sector in the wake of the crisis.

Dramatic government interventions in the economy, which elsewhere we have dubbed "regulation by deal,", are part of the regulatory toolkit, given that our economy remains unhappily prone to disasters. ${ }^{10}$ These deals are a function of some legal constraints that the government faces (including constraints against other ways the financial sector might be rescued), but those constraints are limited, making regulation by deal a policymaking tool that is temptingly flexible. ${ }^{11}$ The dilemma over what to do about semi-seized firms like Fannie Mae and Freddie Mac, therefore, likely exemplifies the sort of problems that we will see during the next crisis and the attendant calls for government takeover or investment. ${ }^{12}$ The lawsuits raise fundamental issues about the extent to which, and for how long, the government can override its standard constraints in pursuit of over-arching policy during emergencies.

a reconstructed housing-finance system will not again produce such a devastating bubble."); Richard A. Posner, Are American CEOs Overpaid, and, If So, What If Anything Should Be Done About It?, 58 DUKE L.J. 1013, 1041 (2009) ("The financial crisis was precipitated by the fact that the risks taken by financial firms were highly correlated and closely tied to housing prices (many of the assets held by banks and other financial institutions were in the form of securities backed by mortgages), so that when the housing bubble burst, much of the world's financial industry was at or over the brink of insolvency.").

${ }^{8}$ Perry Capital, LLC v. Lew, No. 13-1025, 2014 WL 4829559, at *25 (D.D.C. Sept. 30, 2014 (granting the defendants' motion to dismiss and denying the individual plaintiffs' cross-motion for summary judgment).

${ }^{9}$ Steven M. Davidoff \& David Zaring, Regulation by Deal, 61 ADMIN. L. REV. 463 (2009).

10 See generally Charles P. KINDLeberger \& RoBert Z. Aliber, MANIAS, PANICS AND CRASHES 191-212 (6th ed. 2011) (reviewing the cyclical nature of financial crises, and their common features, and concluding that they are ubiquitous features of modern economies); CARMEN M. REINHART \& KeNNETH S. Rogoff, This Time Is DifFerent (2011) (concluding that financial crises are almost unavoidable, even though policymakers tend to exude confidence that they can, in fact, be avoided).

11 Davidoff \& Zaring, supra note 9 , at $465-68$ (describing the constraints faced by the government in the wake of the financial crisis).

${ }^{12}$ Cf. Peter Conti-Brown, Elective Shareholder Liability, 64 STAN. L. REv. 409, 412-13 (2012) (suggesting that shareholders of systemically important financial institutions be required to elect to add "no bailout" provisions to their corporate charters or comply with strict capital requirements as a way to avoid inevitable crisis bailouts). 
In this Article, we offer a solution to the problem of what to do with Fannie Mae and Freddie Mac, and look to the broader implications of what to do in the aftermath of a government response to a crisis. To put the issue in legal terms, when the government takes over and then manages a firm, it is subject to administrative law, which governs state action, and corporate law, which constrains the use that owners and managers make of the firm that they operate. ${ }^{13}$ In our view, the constraints of both kinds of law should be taken seriously when the emergency actions are over and legal consistency is both desirable and necessary. In such cases, the government establishes itself as an owner and fiduciary and must comply with the basic principles of both corporate governance and administrative law-principles that still give the owner and the agency discretion over fundamental business decisions.

We think that administrative procedure must provide the source and limits of much of the constraint on government action, but also that there has to be a thumb on the scale which supports consistency with bedrock principles extant in other bodies of law. That is, when the government is regulating, it is administrative law that evaluates the fundamentals of that regulation. But when the government regulates by deal, it has to comply, at least in some cases, with the requirements of corporate governance, mergers and acquisitions law, and the limitations imposed by the law on controlling shareholders. We think that this blend of corporate and administrative law is novel, and theoretically interesting: in the past, the subjects have not had much to do with one another, but as many of the principles of corporate governance have come to be formed not just by Delaware and deals, but also by Washington and regulations, we suspect that corporate and administrative law will increasingly engage with one another.

More specifically, in the case of Fannie Mae and Freddie Mac, we believe that Treasury's initial actions during the financial crisis were valid. Indeed, Treasury deliberately molded its actions to comply with the laws in effect at the time. However, after the financial crisis, Treasury entered into an agreement with the Federal Housing Finance Agency ("FHFA"), Fannie Mae and Freddie Mac's conservator, which awarded Treasury $100 \%$ of each company's net earnings as a quarterly dividend. ${ }^{14}$ By the second quarter of

$13 \mathrm{Or}$, at least, the government would be so subject if it took over duly incorporated businesses and did nothing to change the charter or the amenability of the firms to suit, as was the case here.

14 See Dep't of the Treasury \& Fed. Nat'l Mortg. Ass'n, Third Amendment to the Amended and Restated Senior Preferred Stock Purchase Agreement (2012), available at http://www.fhfa.gov/Conservatorship/Documents/Senior-Preferred-Stock-Agree/2012-8-

17_SPSPA_FannieMae_Amendment3_508.pdf, archived at http://perma.cc/MS34J3VV?type=pdf [hereinafter Fannie Mae Third Amendment]; Dep't of the Treasury \& Fed. Home Loan Mortg. Ass'n, Third Amendment to the Amended and Restated Senior Preferred Stock Purchase Agreement (2012), available at http://www.fhfa.gov/Conservatorship/Documents/Senior-Preferred-Stock-Agree/2012-817 SPSPA_FreddieMac_Amendment3_N508.pdf, archived at http://perma.cc/5VJ8- 
2013 , the companies had paid $\$ 66.3$ billion to Treasury under the new scheme, as opposed to what would have been a $\$ 4.7$ billion dividend under the original structure. ${ }^{15}$ We believe this dividend was problematic, not just because corporate law ordinarily would not permit this sort of action by the controlling shareholder, but also because it runs afoul of both constitutional and administrative law.

Our analysis has a number of doctrinal implications as well, with consequences not just for this litigation, but for other aspects of administrative, corporate, and bankruptcy law. We conclude that:

- The equitable nature of the entire fairness remedy is consistent with administrative procedure's commitment to equitable remedies, as opposed to damages.

- The conflict of interest faced by the government in deciding whether to keep or share the firms' profits provides an exception to many of the administrative law hurdles faced by shareholders seeking to subject the action of a government conservator to administrative law.

- The fact that two government agencies were involved in the decision about what to do with the GSEs' profits does not authorize the dividend decision, as the agencies did not act at arm's length.

- The GSEs were not in a zone of insolvency that might relax the fiduciary obligations of a controlling shareholder at the time the dividend decision was made, as some have suggested. And, even if they were, the government gave nothing of value to senior creditors in exchange for its decision to take all of the profits of the GSEs, to the detriment of shareholders.

- The Takings Clause offers another doctrinal remedy to the plaintiffs, and it is also plausible, in part because the government's conflict of interest overcomes many of the doctrinal hurdles posed by the government's usual defenses against takings claims.

Of course, the government's conduct as it supervised and owned Fannie Mae and Freddie Mac was not typical regulation. Instead, it exemplifies the

\footnotetext{
JTBG?type=pdf [hereinafter Freddie Mac Third Amendment].

15 See Perry Capital Complaint, supra note 2, $\uparrow 10$. Needless to say, the agreement has turned into a lucrative arrangement for the government. See Shaila Dewan, Fannie Mae Posts Profit that Sets a Record, N.Y. TIMES, Feb. 22, 2014, at B8, available at http://www.nytimes.com/2014/02/22/business/economy/fannie-mae-reports-84-billion-inprofit-for-2013.html, archived at http://perma.cc/CBS3-NZFL (reporting that as of March 2014, Fannie Mae and Freddie Mac will have paid back more in dividends than they received in bailout funds, without any reduction in the debt the companies owe to the government).
} 
controversy that can arise in those rare cases where the government seizes or interferes directly with a business. ${ }^{16}$ In this way, it highlights the ad hoc nature and problematic potential of "regulation by deal." Given that we think the government's action runs afoul of corporate, administrative, and possibly constitutional law, we think that administrative law can provide a route to a remedy that rewards the minority shareholders with stakes in the mortgage giants, without providing them a windfall. Administrative law can do so if it looks to corporate law for the remedy. This solution would require a so-called "entire fairness" analysis, which provides that a deal-in this case, the government's renegotiation of the terms of its dividend arrangement with Fannie Mae and Freddie Mac-is scrutinized to determine if the action is fair to the minority shareholders at the time it was made, both in terms of price and process. ${ }^{17}$

Treasury's decision to award itself all of the profits of Fannie Mae and Freddie Mac would thus be subject to that entire fairness analysis. We think that doing so would likely result in some sort of payment to the minority shareholders, albeit one limited by the deeply impaired value of their holdings. The exact amount, of course, would have to be determined by the court.

Our Article has implications beyond the difficult problem of what to do with Fannie Mae and Freddie Mac. When financial crises come-and these crises are bound to reoccur-the government is likely to take drastic steps to bolster the economy. Sometimes these steps will involve trampling on property and contract rights that in normal times would be sacrosanct; scholars such as Eric Posner and Adrian Vermeule have essentially argued that it is impossible to imagine a way to constrain this sort of action. ${ }^{18}$

We are not so sure. We believe that the government must be permitted to act in a crisis, but that there also must be a limit to the window in which it might act without constraints. When that window closes, and even modestly while it is open, there can and should be some limitations on the government's power to act even in its response to crisis. The post-crisis period, in particular, is not a time to let the government regulate only by deal and emergency decree. Our approach addresses the controversy surrounding the mortgage giants and illustrates some principles that can be used to guide these issues in the future. It is also a lesson for the government's approach in structuring the next "deal" in the inevitable future crisis.

In Part I of this Article, we review the history of Fannie Mae and Freddie Mac - a history that has not ended, even as both firms were among the first to

${ }^{16}$ For a broader account of the government's ownership experience amidst the financial crisis, see Steven M. Davidoff, Uncomfortable Embrace: Federal Corporate Ownership in the Midst of the Financial Crisis, 95 MINN. L. REV. 1733 (2011).

17 We elaborate on this remedy in Part I.B.3, infra.

${ }^{18}$ Eric A. Posner \& Adrian Vermeule, Accommodating Emergencies, 56 STAN. L. REV. 605,609 (2003) (arguing that judicial deference to executive action in times of emergency is inevitable). 
collapse during the financial crisis. In Part II-the doctrinal portion of this Article-we discuss the dispute between the government, which took control of Fannie and Freddie and ultimately decided to pay itself all of the profits made by both firms, and the shareholders seeking dividends on those profits. Because conduct of this sort by a controlling shareholder would ordinarily be governed by corporate law, but in this case is limited by a number of administrative law defenses, the dispute poses a particularly interesting doctrinal puzzle, which we go through in detail. In Part III, we offer our solution to the dispute-a solution that would benefit the remaining shareholders of Fannie and Freddie without offering them a windfall - which we think balances the need for accountability as a financial crisis fades with the need for government flexibility when the crisis is at its apex. In Part IV, we discuss a number of implications of our solution for government deal making, including the right ways to encourage but yet constrain it in a crisis, the role that activist investors might play in this process and in the regulatory process more generally, and the possibility that remedies like the one we propose would over-deter the government.

\section{The RISE AND FALL OF FANNIE AND FREDDIE}

Fannie Mae was established in 1938 as the Federal National Mortgage Association - a government agency designed to facilitate the creation of, and participate in, a secondary market for mortgages, and in that way stabilize the housing market (the market in which most Americans have made their dearest investments). ${ }^{19}$ Fannie Mae's purchases were designed to stabilize the market by providing liquidity for mortgage lenders, thereby backstopping their solvency and encouraging them to lend to homebuyers. ${ }^{20}$ In 1954, Congress converted Fannie Mae from an arm of the bureaucracy to a semi-private corporation in which the federal government held preferred stock and the general public held common stock. ${ }^{21}$ The company was federally chartered but incorporated in Delaware. ${ }^{22}$ Its status as a federally chartered corporation made it a novel mix of public and private; though nominally controlled by shareholders, the firm was often run by former government officials. ${ }^{23}$

${ }^{19}$ National Housing Act Amendments of 1938, ch. 13, 52 Stat. 8 (codified at 12 U.S.C. $\S$ $1716(2012))$.

$20 \mathrm{Id}$.

${ }^{21}$ Housing Act of 1954 , ch. 649,68 Stat. 612 (codified at 12 U.S.C. $\S 1716(2012)$ ).

22 See 12 C.F.R. $\$ 1710.10$ (b)(1) (2014) ("[E]ach Enterprise shall follow the corporate governance practices and procedures of the law of the jurisdiction in which the principal office of the Enterprise is located, as amended; Delaware General Corporation Law, Del. Code Ann. tit. 8, as amended ....").

${ }^{23}$ For a legal overview of the history of Fannie and Freddie, see Julie Andersen Hill, Bailouts and Credit Cycles: Fannie, Freddie, and the Farm Credit System, 2010 WIS. L. REV. 1, 17-23, 27-34, 49-60. For a review by economists (many of whom have never warmed to either of the GSEs), see VIRAL V. ACHARYA ET AL., GUARANTEED to FaIL: 
Moreover, the government afforded the firm tax advantages, and, as a regulatory matter, treated it differently than other financial institutions (it was not supervised, for example, by the usual financial regulators at the Fed or the Office of the Comptroller of the Currency). ${ }^{24}$

In 1970, Congress introduced a companion to Fannie Mae-the Federal Home Loan Mortgage Company, which was soon dubbed Freddie Mac. ${ }^{25}$ Freddie Mac initially focused on purchasing mortgages from thrifts; indeed, it was initially owned by the federal home loan banks that served as a cognate for the Federal Reserve regional banks for thrifts. ${ }^{26}$ It did not restrain itself to thrift purchases, however, entering the broader market for mortgages shortly after its creation. It was privatized entirely in $1989 .{ }^{27}$ Freddie Mac too was federally chartered, but incorporated in Virginia. ${ }^{28}$

The life of Fannie and Freddie prior to the financial crisis was relatively secure. Although chartered by Congress, the two GSEs were theoretically privately owned, ${ }^{29}$ and they purchased most of the mortgages held by financial institutions in the United States, producing rich profits for shareholders. ${ }^{30}$ The companies used these profits to pay their executives millions, many of whom were appointed due to political connections. ${ }^{31}$ Occasionally, a congressman or

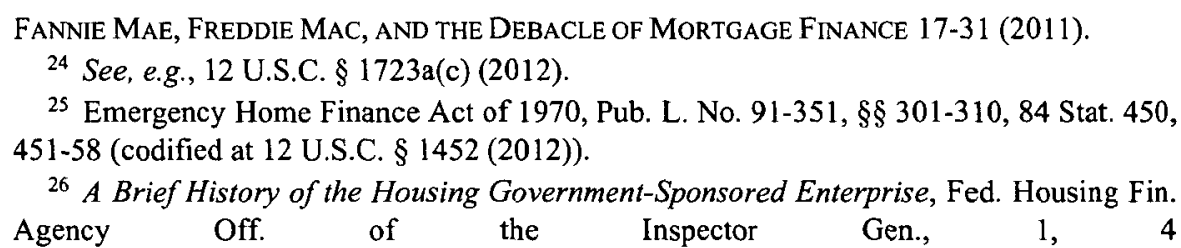
http://fhfaoig.gov/Content/Files/History\%20of\%20the\%20Government\%20Sponsored\%20E nterprises.pdf.

27 Financial Institutions Reform, Recovery, and Enforcement Act of 1989, Pub. L. No. 101-73, § 731(d), 103 Stat. 183, 432.

${ }^{28}$ See Kevin M. Coleman, Are the Feds Forcing Fannie and Freddie into Early Retirement?, 19 FORDHAM J. CORP. \& FIN. L. 489, 516 (2014).

${ }^{29}$ See Fannie Mae, Freddie Mac, and the Federal Role in the Secondary Mortgage Market, CONG. BUDGET OFFICE, 1, 1-3 (2010), available at https://www.cbo.gov/sites/default/files/cbofiles/ftpdocs/120xx/doc12032/12-23-

fanniefreddie.pdf, archived at http://perma.cc/N92U-KRFW?type=pdf (discussing Fannie Mae and Freddie Mac's "hybrid" status as businesses operated for the benefit of their private shareholders that also enjoyed the benefit of special regulatory and tax treatment from the government).

${ }^{30}$ In 2008, Fannie Mae and Freddie Mac issued approximately seventy percent of all mortgage-backed securities, while private banks issued less than ten percent. $I d$. at 7 fig.1.2.

31 Former directors and CEOs of Fannie Mae include Franklin Raines, former Director of the U.S. Office of Management and Budget, and Kenneth Duberstein, former Chief of Staff to President Reagan, advisor to John McCain's Presidential Campaign, and leader of President George W. Bush's transition team. See David S. Hilzenrath, Fannie Mae's Top Executives Leaving Firm: Raines, Howard Out Under Pressure, WaSH. POST (Dec. 22, 2004), http://www.washingtonpost.com/wp-dyn/articles/A17241-2004Dec21.html, archived at 
Treasury Secretary would call for increased regulation of the GSEs, but these movements largely died as Fannie Mae and Freddie Mac regularly spent large sums lobbying Congress. ${ }^{32}$ Even an accounting scandal involving both firms at the turn of the century left them unscathed and largely unregulated, protected by the government's implicit guarantee of their debt. ${ }^{33}$ Most importantly, the two firms enjoyed an implicit government guarantee of their debt, which reduced their borrowing costs and permitted them to dominate the mortgage securitization industry. ${ }^{34}$

Things seemed to be continuing on this basis at the beginning of the financial crisis. When the housing market collapse threatened Fannie and Freddie, the government once again took a number of steps to protect both firms. In July 2008, the Fed offered to provide liquidity to Fannie and Freddie if necessary; Treasury increased the credit available to both firms, and the SEC announced a ban on so-called naked short selling of the firms' securities. ${ }^{35}$

Congress acted as well; indeed, its action showed just how important Fannie and Freddie had become to the nation's financial and housing markets. In July 2008 , shortly after the collapse of the investment bank Bear Stearns, but before the disastrous fall of Lehman Brothers and others in the fall of that year, ${ }^{36}$

http://perma.cc/C7B4-UW3M; Duberstein Resigns from Fannie Mae Board, WASH. POST (Jan. $\quad 12, \quad 2007, \quad 7: 57 \quad \mathrm{PM}$ ), http://www.washingtonpost.com/wpdyn/content/article/2007/01/12/AR2007011201867.html, archived http://perma.cc/9GYQ-Y3L3.

32 See Lisa Lerer, Fannie, Freddie Spent \$200M to Buy Influence, Politico (July 16, 2008, 4:44 AM), http://www.politico.com/news/stories/0708/11781.html, archived at http://perma.cc/ZP3K-6XAJ.

${ }^{33}$ See Kathleen Day, Study Finds "Extensive" Fraud at Fannie Mae; Bonuses Allegedly Drove the Scheme, WASH. POST, May 24, 2006, at A01; Jonathan D. Glater, Market Place; Freddie Mac Gets Penalty and Rebuke over Scandal, N.Y. TIMES, Dec. 11, 2003, at C1.

${ }^{34}$ See Viral V. Acharya, Governments as Shadow Banks: The Looming Threat to Financial Stability, 90 TEX. L. REV. 1745, 1760 (2012); see also Charles Kulp, Assessing the Banking Industry's Exposure to an Implicit Government Guarantee of GSEs, FED. $\begin{array}{lllll}\text { DEPOSIT INS. CORP. } & \text { (Apr. }\end{array}$ http://www.fdic.gov/bank/analytical/fyi/2004/030104fyi.html, archived at http://perma.cc/7C6Q-Q7NW (discussing this implicit guarantee).

35 See Phillip A. Wallach, Legality, Legitimacy and the Responses to the FinANCIAL CRISIS OF 2008 (forthcoming Apr. 2015).

${ }^{36}$ Bear Stearns's collapse and sale to JPMorgan in March 2008 was the first of a series of financial institution failures which culminated in a credit market crisis in September 2008. See generally ANDREW Ross SORKIN, TOO BIG TO FAIL: THE INSIDE STORY OF HOW WALL StREet and Washington Fought to SAVE the Financial System-and ThEMSELves (2010); Andrew Ross Sorkin et al., As Credit Crisis Spiraled, Alarm Led to Action, N.Y. TIMES (Oct. 1, 2008), http://www.nytimes.com/2008/10/02/business/02crisis.html; Landon Thomas Jr., JPMorgan and Fed Move to Bail Out Bear Sterns, N.Y. TIMES (Mar. 14, 2008), http://www.nytimes.com/2008/03/14/business/14cnd-bear.html. 
Congress passed the Housing and Economic Recovery Act of 2008 ("HERA"). ${ }^{37}$

HERA created a new regulator for Fannie Mae and Freddie Mac, FHFA. ${ }^{38}$ It gave that regulator powers to liquidate or place the two GSEs into a conservatorship in the event that the mortgage giants experienced financial distress. ${ }^{39}$ Then-Treasury Secretary Henry Paulson spearheaded the passage of HERA with the expressed intention that the purchasing power granted to FHFA would be theoretical. Paulson phrased his hope memorably: "If you have a bazooka in your pocket and people know it, you probably won't have to use it." 40 Congress meant for HERA to spur private investment in the firms by increasing investor confidence in the stability of Fannie Mae and Freddie Mac.

Paulson's assumption rested on the hope that conservatorship powers would signal to the market that the government was going to provide financial discipline for the GSEs. Unfortunately, after passage of HERA, investor confidence in Fannie Mae and Freddie Mac declined as fears grew that a government conservatorship or liquidation would occur and destroy or diminish the value of Fannie Mae and Freddie Mac's stock and debt. ${ }^{41}$ In short, HERA had the opposite of its intended effect, causing heightened concern among investors that the implicit guarantee for Fannie Mae and Freddie Mac's investors no longer existed.

The decline in confidence was fueled by the brewing financial crisis. Fannie Mae and Freddie Mac's assets were overwhelmingly concentrated in home mortgages and derivative products keyed to them. The risk to Fannie Mae and Freddie Mac as the crisis hit and mortgage values declined was particularly acute since Fannie and Freddie had been permitted to keep a capital buffer as low as $2.5 \%$ of their total assets on hand-much lower than the capital buffers that banks were required to hold. ${ }^{42}$ It was this capital buffer that made the firms, in financial parlance, "heavily leveraged" and "thinly capitalized." 43

${ }^{37}$ Housing and Economic Recovery Act of 2008, Pub. L. No. 110-289, 122 Stat. 2654 (codified at 12 U.S.C. $\$ \S 4501-4602$ (2012)).

${ }^{38}$ Housing and Economic Recovery Act of $2008 \S 1101$ (creating FHFA and delegating to it the power to regulate Fannie Mae and Freddie Mac).

${ }^{39}$ Id. $\S 1145$.

${ }^{40}$ Caroline Baum, Paulson's 'Bazooka' Turned Out to Be Pea Shooter, BLoOMBerG (Aug. 27, 2008, 12:03 AM), http://www.bloomberg.com/apps/news?pid=newsarchive\&sid= ayoDeGZ3yYEc, archived at http://perma.cc/G27X-RPK2.

${ }^{41}$ See id. (describing the firms' dip in value after Paulson's comments and explaining the market's logic).

${ }^{42}$ Andrea J. Boyack, Laudable Goals and Unintended Consequences: The Role and Control of Fannie Mae and Freddie Mac, 60 AM. U. L. REv. 1489, 1524 (2011).

${ }^{43}$ The Congressional Research Service concluded that "[t] the two GSEs were and are very highly leveraged versions of banks." N. ERIC WEISS, CONG. RESEARCH SERV., R42760, FanNIE MaE's and Freddie MaC's FinanCial Status: Frequently Asked Questions 5 (2013), available at http://fas.org/sgp/crs/misc/R42760.pdf, archived at https://perma.cc/9NDQ-HZJR?type=pdf. Then-Federal Reserve Board member Kevin 
Because of the decline in the asset values, and the small amount of capital in place to make up the difference between the lower value of their assets and their still high liabilities, the financial crisis struck the GSEs particularly severely. It was only a matter of time before the two agencies ran out of money, and HERA provided investors with a way for the government to render Fannie and Freddie's private investment worthless.

Soon enough the two thinly capitalized firms did begin to run out of cash. Neither had prepared for the collapse in housing values that precipitated the financial crisis.

On September 7, 2008, the government seized both GSEs and established FHFA as the conservator of their assets. ${ }^{44}$ The government also provided emergency financing to the firms in exchange for preferred shares entitled to a ten percent share of any future profits earned by the GSEs. 45

The deal gave the government a huge- $79.9 \%$, in fact-equity stake 46 in the firms, without, as a technical matter, nationalizing them, possibly because

Warsh concluded that "the institutions were thinly capitalized relative to their asset composition and risk characteristics." Kevin Warsh, Governor, Bd. of Governors of the Fed. Reserve, Speech at the Council of Institutional Investors 2009 Spring Meeting, Washington, D.C. (Apr. 6, 2009) (transcript available at 2013 WL 303293).

44 Press Release, U.S. Dep't of the Treasury, Statement by Secretary Henry M. Paulson, Jr. on Treasury and Federal Housing Finance Agency Action to Protect Financial Markets and Taxpayers (Sept. 7, 2008), available at http:/www.treasury.gov/press-center/pressreleases/Pages/hp1129.aspx, archived at http://perma.cc/LV65-H6WK; Press Release, Fed. Hous. Fin. Agency, Statement of FHFA Director James B. Lockhart at News Conference Announcing Conservatorship of Fannie Mae and Freddie Mac (Sept. 7, 2008), available at http://www.fhfa.gov/Media/PublicAffairs/Pages/Statement-of-FHFA-Director-James-B--

Lockhart-at-News-Conference-Annnouncing-Conservatorship-of-Fannie-Mae-and-FreddieMac.aspx, archived at https://perma.cc/7KK4-YHL7?type=source; see also Press Release, Fed. Hous. Fin. Agency, Questions and Answers on Conservatorship, (Sept. 7, 2008), available at http://www.treasury.gov/press-center/pressreleases/Documents/fhfa_consrv_faq_090708hp1128.pdf, archived at http://perma.cc/2XBA-J7SZ ("The Federal Housing Finance Agency has been appointed to be the Conservator of the Company ... to keep the Company in a safe and solvent financial condition.").

45 See Fannie Mae Third Amendment, supra note 14; Freddie Mac Third Amendment, supra note 14; U.S. Treasury Dep't OfFice of Pub. Affairs, Fact Sheet: Treasury SENIOR PREFERred StOCK PURChase AGREement (Sept. 7, 2008), available at http://www.treasury.gov/press-center/press-releases/Documents/pspa_factsheet

_090708\%20hp1128.pdf, archived at http://perma.cc/P7NQ-FHFC (outlining initial stock purchase agreements). The capital commitment was required to offset the losses on the companies' balance sheets because HERA requires the companies to be placed in mandatory receivership following an extended period of negative net worth. See Housing and Economic Recovery Act of 2008, Pub. L. No. 110-289, 122 Stat. 2654 (codified at 12 U.S.C. $\S \S 4501-4602(2012)) \S 1367(\mathrm{a})(4)$.

${ }^{46}$ The Senior Preferred Stock Purchase Agreements were accompanied by a warrant allowing Treasury to purchase $79.9 \%$ of the companies' common stock at a nominal price 
policymakers found the prospect of taking on an additional $\$ 5$ trillion in mortgage-backed securities, of which $\$ 1.6$ trillion was debt, unappealing given the proximity of the government to its debt ceiling. ${ }^{47}$

The commitment to Fannie Mae and Freddie Mac proved to be a staggering one: Treasury ultimately provided $\$ 188$ billion in capital to Fannie and Freddie by $2012 .{ }^{48}$ Both Fannie Mae and Freddie Mac drew continuously on the capital commitment in every quarter from the initiation of the conservatorship until the second quarter of fiscal year $2012.4^{49}$ The stock purchase agreements were twice amended in order to provide this additional capital to Fannie Mae and Freddie Mac. ${ }^{50}$

(\$0.00001 per share). Fed. Nat'l Mortg. Assoc., Warrant to Purchase Common Stock (Sept. 7 2008), available at http://www.treasury.gov/press-center/pressreleases/Documents/warrantfnm3.pdf, archived at http://perma.cc/RXF4-KMQT; Fed. Home Loan Assoc., Warrant to Purchase Common Stock (Sept. 7, 2008) available at http://www.treasury.gov/press-center/press-releases/Documents/warrantfrec.pdf, archived at http://perma.cc/8WUR-CV9F. The government has never exercised these warrants.

${ }^{47}$ The government's failure to nationalize the GSEs is likely due to a number of reasons. Under the principle of "push-down" accounting, which applies to all companies registered with the SEC, the amount that the parent company paid to acquire the subsidiary gets "pushed down" to the subsidiary, which then uses it as the basis of its valuation. Hugo Numberg, Certain Unresolved Ambiguities in Pushdown Accounting, 80 CPA J. 14, 14 (2010). The threshold for optional push down accounting occurs when the buying company has acquired eighty percent of a company and it becomes mandatory after acquiring ninetyfive percent. See generally id. By purchasing only $79.9 \%$, the government could

build a case that each GSE was not now a government-controlled entity so that the government's unique accounting rules did not have to be adopted . . . ; to ensure that these GSEs could still deduct interest paid on their loans from the government, something they would be unable to do under $\S 163$ of the Internal Revenue Code if they were deemed "controlled" by the government; and . . to ensure for Employee Retirement Income Security Act (ERISA) purposes that the GSEs were not deemed "controlled" by the government, making the government joint and severally liable for these entities' ERISA plan liabilities.

Davidoff \& Zaring, supra note 9, at 489; see also Adam Levitin, Why Have the Government Bailouts Involved Only a 79.9\% Equity Position?, CREDITSLIPS (Sept. 18, 2008, 11:00 PM) http://www.creditslips.org/creditslips/2008/09/why-have-the-go.html, archived at perma.cc/RXZ2-827P; Steven M. Davidoff, Who Owns A.I.G. (a Continuing Story), N.Y. TiMES DeALBooK (Oct. 7, 2010, 9:10 AM), http://dealbook.nytimes.com/2010/10/07/whoowns-a-i-g-a-continuing-story/, archived at perma.cc/5JW6-PBD9.

48 Through the end of Q1 FY2012, Fannie Mae drew on $\$ 116.2$ billion and Freddie Mac drew on $\$ 71.3$ billion for a total draw of $\$ 187.5$ billion. FED. Hous. FIN. AGENCY, 2013 PERFORMANCE AND ACCOUNTABILITY REPORT 110 (2013), available at http://www.fhfa.gov/AboutUs/Reports/ReportDocuments/2013_PAR_N508.pdf, archived at https://perma.cc/CV7Y-9JXR?type=pdf.

${ }^{49}$ Id.

s0 See Dep't of the Treasury \& Fed. Nat'l Mortg. Ass'n, First Amendment to the Amended and Restated Senior Preferred Stock Purchase Agreement (2009); Dep't of the Treasury \& Fed. Nat'l Mortg. Ass'n, Second Amendment to the Amended and Restated 
In August 2012, Treasury and FHFA entered into a third amendment to the stock purchase agreements (the "Third Amendment"), which replaced the tenpercent dividend with a "full income sweep," by which Treasury would receive a dividend equal to the total quarterly profits of each company. ${ }^{51}$ At the time, Michael Stegman, Counselor to the Secretary of the Treasury for Housing Finance Policy, stated that Treasury was "taking the next step toward responsibly winding down Fannie Mae and Freddie Mac, while continuing to support the necessary process of repair and recovery in the housing market." ${ }^{52}$ Treasury explicitly stated that the goal of this revision was to make "sure that every dollar of earnings that Fannie Mae and Freddie Mac generate will be used to benefit taxpayers for their investment in those firms." 53

Treasury intended to ensure that the firms never paid dividends to the common and junior preferred stock in Fannie Mae and Freddie Mac still outstanding after the quasi-nationalization, regardless of how profitable the firms became. Because a share in a company is only worth its claim on future corporate profits, the Third Amendment rendered the common and junior preferred stock worthless. ${ }^{54}$ The government intervention left Fannie and Freddie debt-holders untouched, paying them 100 cents on the dollar. ${ }^{55}$

Senior Preferred Stock Purchase Agreement (2009); Dep't of the Treasury \& Fed. Home Loan Mortg. Ass'n, First Amendment to the Amended and Restated Senior Preferred Stock Purchase Agreement (2009); Dep't of the Treasury \& Fed. Home Loan Mortg. Ass'n, Second Amendment to the Amended and Restated Senior Preferred Stock Purchase Agreement (2009).

${ }^{51}$ Fannie Mae Third Amendment, supra note 14; Freddie Mac Third Amendment, supra note 14; see also Press Release, U.S. Dep't of the Treasury, Treasury Department Announces Further Steps to Expedite Wind Down of Fannie Mae and Freddie Mac (Aug. 17, 2012), available at http://www.treasury.gov/press-center/pressreleases/Pages/tg1684.aspx, archived at http://perma.cc/E2LW-Y84H [hereinafter Wind Down Press Release] (announcing the Third Amendment as a step to "help expedite the wind down of Fannie Mae and Freddie Mac, make sure that every dollar of earnings each firm generates is used to benefit taxpayers, and support the continued flow of mortgage credit during a responsible transition to a reformed housing finance market").

52 Wind Down Press Release, supra note 51; see also Press Release, Fed. Housing Fin. Agency, Statement of FHFA Acting Director Edward J. DeMarco on Changes to Fannie Mae and Freddie Mac Preferred Stock Purchase Agreements (Aug. 17, 2012), available at http://www.fhfa.gov/Media/PublicAffairs/Pages/Statement-of-FHFA-Acting-Director-

Edward-J-DeMarco-on-Changes-to-Fannie-Mae-and-Freddie-Mac-Preferred-Stock-

Purchas.aspx, archived at https://perma.cc/Y2W4-9FJ5?type=image.

53 Wind Down Press Release, supra note 51.

54 See Robert J. Shiller, From Efficient Markets Theory to Behavioral Finance, $17 \mathrm{~J}$. ECON. PERSP. 83, 84-85 (2003) ("The efficient markets model can be stated as asserting that the price $P_{t}$ of a share ... equals the mathematical expectation, conditional on all information available at the time, of the present value $P^{*}{ }_{1}$ of actual subsequent dividends accruing to that share . . . $P^{*}$, is not known at time $t$ and has to be forecasted. Efficient markets say that price equals the optimal forecast of it.").

s5 See Mark Jickling, Cong. Research Serv., RS22950, FanNiE MAE and Freddie 
By the time of the Third Amendment, the housing markets had stabilized, and the firms became profitable in $2012 .{ }^{56}$ In the second quarter of 2012 , the net worth sweep dividends soon exceeded the ten-percent dividend contemplated by the terms of the original takeover, leaving plenty of profits, which, under the initial stock purchase agreements, could have been paid to Fannie and Freddie shareholders who had retained their stakes in the seized firms. ${ }^{57}$ The firms have paid Treasury $\$ 182.4$ billion in net worth sweep dividends since the Third Amendment, an amount almost equal to the capital commitment provided by Treasury. ${ }^{58}$ For this reason, both junior preferred and common stockholders filed multiple complaints against both Treasury and FHFA in the United States District Courts for the District of Columbia, the Southern District of Iowa, and the Court of Federal Claims over the government's actions in connection with the Third Amendment. ${ }^{59}$ The complaints fall into three categories. The first set of complaints consist of those brought by hedge funds, including Perry Capital, Pershing Square Capital Management, Fairholme Funds, and others who have, subsequent to the conservatorship of Fannie and Freddie, purchased preferred or common shares on the open market. ${ }^{60}$ Second is a shareholder class action brought in the same court on behalf of all the preferred and common shareholders at the time of the

\footnotetext{
MAC IN CONSERVATORSHIP 2-3 (2008), available at

http://fpc.state.gov/documents/organization/1 10097.pdf, archived at http://perma.cc/PM2AF6DX.

56 See Cheyenne Hopkins \& Clea Benson, U.S. Revises Payment Terms for Fannie Mae, Freddie Mac, BloOMBERG (Aug. 17, 2012, 9:28 PM), http://www.bloomberg.com/news/2012-08-17/treasury-accelerates-withdrawal-of-fanniefreddie-backing.html, archived at https://perma.cc/J8EE-XNHA?type=image (writing that at the time of the Third Amendment, Fannie Mae and Freddie Mac had both reported profits for the quarter sufficient to pay the ten-percent dividend to Treasury without further drawing on the capital commitment).

57 See Coleman, supra note 28, at 509.

${ }^{58}$ In 2013 alone, the two firms paid Treasury $\$ 132.4$ billion in net worth sweep dividends. See Fed. Home Loan Mortg. Corp., Annual Report (Form 10K) 226 (Feb. 27, 2014), available at http://www.freddiemac.com/investors/er/pdf/10k_022714.pdf, archived at https://perma.cc/RE32-U7TW?type=pdf; Fed. Nat'l Mortg. Ass'n., Annual Report (Form 10K) (Feb. 27, 2014), available at http://www.fanniemae.com/resources/file/ir/pdf/quarterly-annual-

results/2013/10k_2013.pdf, archived at http://perma.cc/AZ4G-KJJB; Press Release, Fannie Mae, Fannie Mae Reports Comprehensive Income of \$84.8 Billion for 2013 and \$6.6 Billion for Fourth Quarter 2013 (Feb. 21, 2014), available at http://www.fanniemae.com/resources/file/ir/pdf/quarterly-annualresults/2013/q42013_release.pdf, archived at https://perma.cc/QF98-3P6M?type=pdf.

59 See supra note 2.

${ }^{60} I d$.
} 
Third Amendment. ${ }^{61}$ Finally, some, but not all, of the hedge funds have brought takings claims in the Court of Federal Claims. ${ }^{62}$

The complaints allege violations of the Administrative Procedure Act ("APA") with respect to the Third Amendment on the grounds that it violated HERA and was, in any event, an "arbitrary and capricious" action. ${ }^{63}$ The shareholder class action and the Fairholme Complaint go further, alleging that the Third Amendment breached the terms of the common and preferred stock as well as the fiduciary duties of Treasury and FHFA with respect to Fannie Mae. ${ }^{64}$ The shareholder class action and the Pershing Square Complaint also allege that the Third Amendment deprived shareholders of dividends in violation of the Fifth Amendment Due Process Clause. ${ }^{65}$ The Pershing Square Complaint also alleges a derivative breach of implied contract between the FHFA and the GSEs, that FHFA failed to "preserve the Companies' assets and property" in conservatorship. ${ }^{66}$

The Court of Federal Claims has allowed the plaintiffs to proceed to discovery on their claims. However, on September 30, 2014, the district court in Washington dismissed the consolidated shareholder complaints before it. 67 The basis for the court's ruling was three-pronged. First, the court held that the government's seizure of Fannie's and Freddie's profits did not violate the APA's prohibition on "arbitrary and capricious" conduct. ${ }^{68}$ It also found that HERA barred shareholders of Fannie and Freddie from bringing breach of fiduciary duty suits against the boards of the companies and that the government's seizure of profits was not an unconstitutional "taking." 69 On February 3, 2015, the district court in Iowa made a similar ruling, noting, if only in a footnote, that "it would agree with the well-reasoned opinion of the very able Judge Lamberth in Perry Capital that the case must be dismissed."70

${ }^{61}$ Shareholder Class Action Complaint, supra note 2, at 21.

${ }^{62}$ See, e.g., Complaint, Fairholme Funds v. United States, No. 1:13-cv-00465-MMS (C.F.C. Sept. 7, 2013).

63 See, e.g., Class Action Complaint, Cacciapelle v. Fed. Nat'l Mortg. Ass'n, No. 1:13CV-01149, 2013 WL 3878466, at 7 7a (D.D.C. July 29, 2013); Shareholder Class Action Complaint, supra note 2, at \22; Fairholme Funds Complaint, supra note 2, at $\ 14$.

${ }^{64}$ See Shareholder Class Action Complaint, supra note 2, at I 21; Fairholme Funds Complaint, supra note 2 , at $\{15$.

${ }^{65}$ See Shareholder Class Action Complaint, supra note 2, at ๆ 26.

${ }^{66}$ See Pershing Square Complaint, supra note 2, at \% 85.

${ }^{67}$ See Perry Capital v. Lew, No. 13-cv-1025, 2014 WL 4829559 (D.D.C. Sept. 30, 2014) (per curiam).

${ }^{68} \mathrm{Id}$.

${ }^{69}$ Id.; see also David Zaring \& Steven Davidoff Solomon, Fannie-Freddie Case Shows Messy Nature of Deal-Making in a Panic, N.Y. TIMES DealBook (Oct. 2, 2014, 4:00 PM), http://dealbook.nytimes.com/2014/10/02/fannie-freddie-case-shows-messy-nature-of-dealmaking-in-a-panic, archived at http://perma.cc/M9F7-FMAB.

${ }^{70}$ Cont'l W. Ins. Co. v. Fed. Hous. Fin. Agency, No. 4:14-cv-00042, 2015 WL 428342, at *10 n.6 (S.D. Iowa, Feb. 3, 2015). 
The plaintiffs are appealing this dismissal to the D.C. Circuit Court of Appeals, and the final resolution of the dispute will come after the publication of this Article, which nonetheless may inform how that dispute should be resolved, and will represent a statement about what the courts should do in future cases like it. ${ }^{71}$

\section{WHERE CORPORATE AND ADMINISTRATIVE LAW MEET}

In this Part, we delve into the legal issues raised by the government's treatment of Fannie and Freddie's remaining shareholders and the lawsuits that have arisen from that treatment. We begin with an overview of the legal doctrines at stake. This might be thought of as an answer to the question: how could the government possibly win this case? We delve into the doctrines, many of which are animated by the government's sovereign immunity from suit absent an explicit waiver that suit be permitted. These doctrines give the government technical defenses in a case where the equities are less than compelling. We then analyze the corporate law issues posed by the government's actions in the case, which would ordinarily protect minority investors such as the plaintiffs.

Generally, it would be virtually impossible for a controlling shareholder of a firm to unilaterally award itself all of the firm's dividends at the expense of minority shareholders. ${ }^{72}$ But administrative law contains a number of doctrines that favor government agencies acting within their statutory remit. These doctrines have offered defenses both for Treasury and for FHFA as conservator of the assets of the mortgage giants in assessing the legality of their treatment of the firms' preferred shareholders.

These administrative law doctrines include the principle of sovereign immunity, which protects the government from being sued over its actions except where expressly permitted by a clear statement from Congress. ${ }^{73}$ HERA itself does not waive either FHFA's or Treasury's sovereign immunity. ${ }^{74}$

${ }^{71}$ Notice of Appeal, Perry Capital v. Lew, No. 14-253 (D.C. Cir. Oct. 8, 2014); Notice of Appeal, Perry Capital v. Lew, No. 13-cv-1025 (D.D.C. Oct. 2, 2014).

72 Such an act would be reviewed for compliance with the majority shareholders' fiduciary duties, and they would have to show it was "entirely fair." See Weinberger v. UOP, Inc., 457 A.2d 701, 703-04 (Del. 1983) (placing burden of showing intrinsic fairness in squeeze-out merger on controlling majority shareholder); see also Sinclair Oil Corp. v. Levien, 280 A.2d 717, 720 (Del. 1971) ("When the situation involves a parent and a subsidiary, with the parent controlling the transaction and fixing the terms, the test of intrinsic fairness, with its resulting shifting of the burden of proof, is applied."). This review encompasses a determination as to fair process and fair price. While this is discussed further infra notes 91-94 and accompanying text, it is difficult to conceive of how a majority shareholder in a company without distress could justify this action as "fair." This analysis differs from that applied to differential treatment of different classes of shares, where governing documents may rule.

${ }^{73}$ See generally Katherine Florey, Sovereign Immunity's Penumbras: Common Law, "Accident," and Policy in the Development of Sovereign Immunity Doctrine, 43 WAKE 
Moreover, HERA, like other statutes affording powers to financial regulators, contains an anti-injunction component, which makes it more difficult for a court to award the sort of equitable relief that an aggrieved minority shareholder might pursue against majority oppression. ${ }^{75}$

Courts also defer to agency interpretations of ambiguous statutory terms within the laws that the agency is charged with implementing. ${ }^{76}$ Agencies are generally permitted to act pursuant to any reasonable interpretation of their statutory remit. Financial regulators, in particular, benefit from a hands-off judicial approach to policies implemented with an eye to safeguarding the economy; courts appear to view themselves as inexpert in interpreting this form of regulation, and so, although nothing in legal doctrine requires it, they have essentially concluded that many aspects of financial regulation, such as monetary policy and rescue decisions, are inhospitable to review. ${ }^{77}$

Finally, financial regulators, like all agencies, benefit from the timing and nature of jurisdictional doctrines such as ripeness and standing, which make it difficult for would-be plaintiffs to file suit. ${ }^{78}$

These legal doctrines, designed to afford regulators a measure of discretion in implementing policy, fit uncomfortably with the role the government plays when it acts as a corporate manager. An agency is not a profit maximizer, which is what is roughly expected of the manager of a firm in private hands. An agency also has defenses to the obligations we expect of controlling shareholders.

Corporate law, however, is designed to structure relationships among managers, shareholders, and officers in ways that directly affect what any controlling shareholder can do, even if that shareholder is a government entity. In particular, fiduciary duties regulate the actions of both managers and officers. ${ }^{79}$ Courts impose heightened fiduciary duties on controlling

FOREST L. REV. 765, 771-84 (2008) (explaining the different types of sovereign immunities and their histories).

7412 U.S.C. $\$ 4617(j)$ (4) (2012) ("The Agency shall not be liable for any amounts in the nature of penalties or fines, including those arising from the failure of any person to pay any real property, personal property, probate, or recording tax or any recording or filing fees when due.").

${ }^{75} I d$. (" $[\mathrm{N}] \mathrm{o}$ court may take any action to restrain or affect the exercise of powers or functions of the Agency as a conservator.").

76 See Chevron U.S.A. Inc. v. Natural Res. Def. Council, Inc., 467 U.S. 837, 843-45 (1984) (holding that courts must defer to "permissible construction" of statutes by agencies).

77 David Zaring, Administration By Treasury, 95 MINN. L. REV. 187, 190-94 (2010).

${ }^{78}$ See, e.g., Abbott Labs. v. Gardner, 387 U.S. 136, 148-49 (1967) (requiring courts to abstain from reviewing agency action prematurely).

${ }^{79}$ Gantler v. Stephens, 965 A.2d 695, 708-09 (Del. 2009) (holding that officers of Delaware corporations owe the same fiduciary duties of care and loyalty as directors); see also Cede \& Co. v. Technicolor, Inc., 634 A.2d 345, 361 (Del. 1993) (holding that directors owe fiduciary duties of care and loyalty). 
shareholders in order to prevent misconduct towards minority shareholders. ${ }^{80}$ This includes a requirement that controlling shareholders follow certain procedures when "freezing-out" minority shareholders or otherwise have their conduct be scrutinized by the courts for "entire fairness." 81

Despite these obligations, which apply to anyone who runs a corporation, Treasury structured its initial deal to take over the mortgage giants without heeding how its conduct might implicate these duties. In particular, leaving behind a publicly traded float created not just fiduciary duty problems but also a class of holders to inevitably assert these issues. To be sure, Treasury's actions were in part explained by its regulation by deal approach, which encompassed quickly done transactions made on an ad hoc basis. Forethought for actions years down the road was difficult in this environment and arguably not a predominant factor in the government's calculus. At the time, government officials simply wanted to rescue the economy and the targeted financial institutions, including Fannie Mae and Freddie Mac.

However, even at the time, Ed Rock and Marcel Kahan warned that the government, when it took control of companies, would create difficult problems for corporate law. ${ }^{82}$ Professors Rock and Kahan argued that:

when the government is an investor, ex post judicial review under the heading of "fiduciary duties" becomes less effective, and greater attention must be given to the ex ante governance structures used when the government takes an equity position as well as to the potential virtues of precommitment to early exit. ${ }^{83}$

Their prediction has come to pass following the bailouts as the government takeover suggests. It is easy to sympathize with the government's motives, if not its means, with regard to the post-takeover treatment of Fannie Mae and Freddie Mac. The government, after all, saved them. The parties who have continued to hold stakes in the companies are hedge funds and other

${ }^{80}$ Weinberger v. UOP, Inc., 457 A.2d 701,710 (Del. 1983) (holding that boards of directors have a duty of loyalty to their shareholders); see generally 12B WILLIAM MEADE Fletcher et al., Fletcher CyClopedia of THE LAW of PRIVATE CORPORATION $\$ 5713$ (perm. ed., rev. vol. 2000) (explaining that majority shareholders in many jurisdictions owe a duty of care, loyalty, and good faith).

81 See Kahn v. M\&F Worldwide Corp., 88 A.3d 635, 645 (Del. 2014); Glassman v. Unocal Exploration Corp., 777 A.2d 242, 247-48 (Del. 2001); In re Siliconix Inc. Shareholders Litig, No. CIV. A. 18700, 2001 WL 716787, at*6 (Del. Ch. June 19, 2001). See generally Guhan Subramanian, Fixing Freezeouts, 115 YALE L.J. 2, 8-29 (2005) (discussing history and evolution of freeze-outs of minority shareholders).

${ }^{82}$ Marcel Kahan \& Edward B. Rock, When the Government is the Controlling Shareholder, 89 TEX. L. REV. 1293, 1346-47 (2011) (discussing the problems created by jurisdictional limitations on judicial review of agency action even where that action would be clearly illegal if attempted by a private shareholder).

83 Id. at 1298. 
speculators; ${ }^{84}$ they did not stand by the mortgage giants during the crisis, and they did not serve as the government's willing supporters when it sought to rescue and stabilize the firms. ${ }^{85}$ Yet, the government structured its deal and failed to fully address the issues at the time.

This failure preserved legal rights-the scope of which are now being litigated - that the GSEs' shareholders maintained. Treasury has said that it is uninterested in providing the firms' remaining shareholders with a dividend ${ }^{86}$ But if the government, in making its deals, elected to preserve a stub of private shareholders in the course of a rescue, its subsequent management of the rescued firm was sure to implicate the rights of the stub. By choosing to do so, the government did not give itself license to treat minority shareholders in any way that it wished; nor would we want the government to have the power to seize businesses, run them for years, and decide to one day zero out the minority shareholders that retain parts of the firm.

The question, of course, is what rights did these shareholders retain and from where do they spring? The government's actions accordingly pit fundamental doctrines of corporate law against some of the government's strongest advantages in administrative law. In what follows, we review the way that this legal puzzle might be resolved.

\section{A. The Corporate Law Case Against the Government}

Fannie Mae and Freddie Mac are hybrid creatures, created by the federal government but run as publicly traded corporations. As public corporations, they are subject to the full panoply of the federal securities laws for companies that register their shares under the Securities Exchange Act of $1934 .{ }^{87}$ In addition, courts have held that fiduciary duties apply to Fannie Mae and Freddie Mac's officers and directors. ${ }^{88}$ State law fiduciary duties accordingly

${ }^{84}$ See, e.g., Jody Shenn, Westhus Reaping Fannie Windfall to Rival Big Short: Mortgages, BLOOMBERG (Mar. 10, 2014, 4:28 PM), http://www.bloomberg.com/news/201403-10/westhus-reaping-fannie-windfall-to-rival-big-short-mortgages.html, archived at https://perma.cc/3CBU-5543?type=image (observing that investor speculation in Fannie Mae and Freddie Mac resulted in massive stock price increases in 2013).

85 Prior to investor speculation following the net worth sweep dividends, Fannie Mae's common stock traded for less than one dollar in 2011 and 2012. See FNMA:US Stock Chart, BLOOMBERG, http://www.bloomberg.com/quote/FNMA:US/chart (last visited Apr. 24, 2014).

${ }^{86}$ Wind Down Press Release, supra note 51 (announcing that every dollar earned by Fannie Mae and Freddie Mac will benefit taxpayers for their investment in the firms).

${ }^{87}$ Initially, both Fannie Mae and Freddie Mac were exempt from securities laws, but they became subject to those laws when they voluntarily registered their securities. See generally Richard E. Mendaies, Collateralized Explosive Devices: Why Securities Regulation Failed to Prevent the CDO Meltdown, and How to Fix It, 5 U. ILL. L. REv. 1359, 1366-67 (2009).

${ }^{88}$ See In re Fed. Nat'l Mortg. Ass'n Sec., Deriv., \& “ERISA" Litig., 503 F. Supp. 2d 9, 14 (D.D.C. 2007). 
regulate the types of action Treasury took when it imposed the Third Amendment. Treasury and FHFA are controlling shareholders with fiduciary duties to the remaining public shareholders of Fannie and Freddie. ${ }^{89}$ Since the transaction at issue is a conflicted interest transaction, it would be subject to approval by either the disinterested directors or stockholders. ${ }^{90}$ If such approval was not obtained, as is the case with Fannie and Freddie, then the controlling shareholder would be required to show that the transaction was "entirely fair."

The entire fairness principle applies in a straightforward way in this instance. ${ }^{91}$ Treasury would be required to show that the Third Amendment was fair both from a price and process perspective. ${ }^{92}$ Process in this context would be due process, which we believe would be required both by the Constitution and by the APA-Congress's effort to delineate the process due those aggrieved by federal agency action..$^{93}$ The test would then ultimately boil down to whether Treasury can show that the "price" paid by Fannie and Freddie for this amendment was fair. To do this, Treasury would focus on whether the GSEs retained value at the time of the Third Amendment and whether Treasury gave anything in exchange for the amendment. 94

Admittedly, the state laws, which largely follow Delaware precedent, do not perfectly fit. These laws were never designed to apply to a governmentcontrolled corporation with public shareholders. Still, in cases with similar fact

${ }^{89}$ See Sinclair Oil Corp. v. Levien, 280 A.2d 717, 720 (Del. 1971) (explaining that parent companies owe a fiduciary duty to their subsidiaries when the two companies deal with one another, and that the intrinsic faimess standard adheres when the fiduciary duty is accompanied by self-dealing).

${ }^{90}$ DEL. CODE ANN. tit. 8, $\S 144$ (2011) applies here because the controller sits on both sides of the transaction. Virginia has a similar statute. VA. CODE ANN. § 13.1-871 (2011 \& Supp. 2014).

${ }^{91}$ Treasury has claimed in legal filings that it is not a controlling shareholder because Fannie and Freddie individually made these decisions, but we find no support for this argument in corporate law.

${ }^{92}$ For a detailed exposition of this analysis, see Weinberger v. UOP, Inc., 457 A.2d 701, 710 (Del. 1983). Additionally, Treasury and FHFA would bear the burden of proof to show that their actions were "entirely fair." Id. See also tit. 8, § 144.

${ }^{93}$ See, e.g., Peter H. Schuck, Foundations of Administrative Law 53 (2d ed. 1994) (describing the APA as "a quasi-constitutional statute" and suggesting that "[i]f there were no APA, the courts . . . would certainly have invented something like it in order to implement the constitutional safeguards of the Fifth Amendment's due process clause"). See also Evan J. Criddle, When Delegation Begets Domination: Due Process of Administrative Lawmaking, 46 GA. L. REV. 117, 177 (2011) ("Deliberative administrative procedures like those in the APA thus satisfy due process by honoring the republican values that are implicit in the Constitution's structure.").

94 This analysis would apply both with respect to the common shares and preferred shares of Fannie and Freddie. See Jedwab v. MGM Grand Hotels, Inc., 509 A.2d 584, 594 (Del. Ch. 1986) (holding that board of directors owed equal fiduciary duty to both preferred and regular stockholders). 
patterns, Delaware has uniformly applied a higher fiduciary duty to protect minorities from the actions of controllers. ${ }^{95}$ Privatized utilities, in which a government entity retains a stake, for example, are also not immune from the dictates of corporate law. ${ }^{96}$

Another way to look at the situation is that Treasury performed a "freezeout," a transaction in which a controlling shareholder squeezes out the minority shareholders. In that context, there has been a thirty-year debate in corporate law over how these transactions should be policed. ${ }^{97}$ But the polestar has been that in the absence of evidence of arms-length dealing, the entire fairness standard governs. ${ }^{98}$ And as we discuss below, there does not appear to be armslength dealing here.

We explore this more below, but this would essentially devolve into a question of fact encompassing two areas. First, what were Treasury's obligations under the prior arrangements? Did Treasury have the obligation to continue to support the GSEs such that the amendment was unilateral? Second, what was the collective financial state of the GSEs at the time of the amendment, and given that state, did Treasury appropriate value from the minority shareholders? Here again, there will be the question of what return Fannie and Freddie received in exchange for the Third Amendment.

Such a lawsuit could be promising for shareholders, without offering them a windfall. At the time of the Third Amendment, Fannie and Freddie had both experienced profitable quarters. ${ }^{99}$ Some argued that the housing market was in recovery. ${ }^{100}$ Even though prior to the Third Amendment the GSEs would have had to pay back $\$ 5$ billion before either preferred or common shareholders received anything, the GSEs' mere existence provided residual value beyond any profit potential.

Adam Badawi and Anthony Casey have thoughtfully argued that the preferred and common stock of the GSEs had no value at the time of the Third Amendment and so the fiduciary duties of Fannie and Freddie's officers, directors, and controlling shareholder ran to the whole firm. ${ }^{101}$ This would

95 See, e.g., Sinclair Oil Corp. v. Levien, 280 A.2d 717, $721-22$ (Del. 1971).

96 See, e.g., id. at 723 (finding breach of contract by privatized utility company for failing in fiduciary duties to subsidiary).

97 See Ronald J. Gilson \& Jeffrey N. Gordon, Controlling Controlling Shareholders, 152 U. PA. L. REV. 785, 786 (2003) (arguing that Delaware should give freeze-outs "“business judgment rules' protection" when "approved by a genuinely independent special committee that has the power to say 'no' to a freeze-out merger").

${ }^{98}$ Levien, 280 A.2d at 720 ("[The intrinsic fairness] standard will be applied only when the fiduciary duty is accompanied by self-dealing.").

${ }^{99}$ Coleman, supra note 28, at 509 ("Fannie Mae, in the second quarter of 2012, reported a $\$ 2.8$ billion profit, which accounted for its dividend obligations to the Treasury. Similarly Freddie Mac reported a $\$ 2.9$ billion profit during the same timeframe.").

100 See, e.g., id.

101 Adam B. Badawi \& Anthony J. Casey, The Fannie and Freddie Bailouts Through the Corporate Lens (Univ. of Chi. Law Sch. Coase-Sandor Inst. Law \& Econ., Working Paper 
result in the managers owing fiduciary duties to the companies' creditors, as opposed to the shareholders. ${ }^{102}$ In such a circumstance, they contend, the corporate law claims of Fannie and Freddie's shareholders, which depend on those duties being owed to them alone, would fail, although Casey and Badawi also think that, because the common and junior preferred shares were worthless at the time of the Third Amendment, there would be no money to be awarded to the shareholders. ${ }^{103}$ We think that ultimately, this conclusion is consistent with ours in some ways, since under Casey and Badawi's theory, a determination will need to be made as to the state of the GSEs-a determination which, in essence, duplicates the fair price step of the entire faimess analysis.

Moreover, to the extent that the zone of insolvency permits the firms' managers to consider creditors' interests in addition to the shareholders', it is not clear that Treasury gave anything of value to the creditors who sat above it in exchange for the Third Amendment. ${ }^{104}$ Instead, the sweep agreement only imposes obligations on Fannie Mae and Freddie Mac. ${ }^{105}$ As Richard Epstein has observed, "the transaction was all quid without any pro quo."106 Treasury may have taken on some payment risk, given that it changed its take from a ten-percent dividend to all of the firms' profits (which could have theoretically been lower than that ten-percent stake). ${ }^{107}$

No. 684, 2014), available at http://ssrn.com/abstract $=2410887$.

102 See id.

${ }^{103} I d$.

104 See N. Am. Catholic Educ. Programming Found., Inc. v. Gheewalla, 930 A.2d 92, 103 (Del. 2007) (giving creditors the right to assert derivative, but not direct claims against directors who have breached obligations to a firm in the zone of insolvency); Prod. Res. Grp., L.L.C. v. NCT Grp., Inc., 863 A.2d 772, 790 (Del. Ch. 2004) (when a firm is in the zone of insolvency, directors may work to preserve creditor value even if it's not the best thing for shareholders).

${ }^{105}$ The full income sweep provisions in the Third Amendment did not include any additional injection of capital into the GSEs, nor did they forgive any existing balance owed to Treasury. See Fannie Mae Third Amendment, supra note 14; Freddie Mac Third Amendment, supra note 14.

${ }^{106}$ Specifically, Epstein observes that the Third Amendment "offers no new consideration to Fannie and Freddie, so that 'all positive net income each quarter will be swept to the Treasury,' without any reduction in the amount of the principal owing with respect to the senior preferred." Richard A. Epstein, The Government Takeover of Fannie Mae and Freddie Mac: Upending Capital Markets with Lax Business and Constitutional Standards, 12 NYU J.L. \& BUS. (forthcoming 2015).

107 We recognize the argument that the amendment gave value to the senior creditors of the GSEs by accelerating the wind-down of the company and therefore preserving value for the creditors. Badawi \& Casey, supra note 101 . However, this too would require a judicial analysis of whether the life of the GSEs was cut short just when they had returned to profitability, again implicating the entire fairness analysis. 
But if anything, it was likely a prospect in the minds of government regulators that both firms were about to become profitable, as indeed they immediately did. ${ }^{108}$ Moreover, Treasury had already provided these firms with a substantial amount of liquidity, and it is implausible that it would not have continued to support the institutions in 2012. Treasury thus neither reduced the riskiness of Fannie and Freddie in exchange for all if its profits, nor solved a liquidity problem. In short, it is difficult to see how creditors benefited in any way from the Third Amendment, while the injury to shareholders junior to Treasury is obvious.

In any event, we are not so sure that a court would conclude that the GSEs were insolvent given their contractual obligations with Treasury for funding the two GSEs at the time-assets to be sure. ${ }^{109}$ Their insolvency claim rests on the argument that at the time of the Third Amendment, it was inconceivable that Fannie and Freddie could have repaid the amount owed to Treasury. Yet, we believe that this is not the calculus under corporate law-rather, the determination is whether the company is insolvent. Fannie and Freddie were solvent if they could service their debt loads at that time (the so-called "cash flow" test) and their assets exceeded their liabilities (the so-called "balance sheet" test). ${ }^{110}$ In this calculus the Treasury funding commitments would have to be counted as assets for the GSEs, despite their being relics of Treasury's prior deals. Given this, we think it hard to find that either GSE was insolvent at the time of the Third Amendment for purposes of Delaware law. In any event, this is a matter for expert testimony and further analysis-we believe that it is not a closed question and that under pure corporate law there exists a litigable claim. We analyze the shareholders' case and remedy further in the next Part.

\section{B. Corporate Law Meets Administrative Law}

The corporate case has real barriers in administrative law, and in this section, we review the doctrinal gymnastics required to get at what we believe corporate law requires and administrative law should permit. Lawyers will find the puzzles posed by the case interesting; legal realists may be less inclined to follow every move that must be made to deal with this or that precedent and this or that statutory directive. We offer the analysis not because we think the

108 See id. ("By August 2012, it appeared that things were getting better. The Entities had just experienced two quarters of profit.").

109 The question of whether these contracts would be enforceable in bankruptcy is arguably an open one as courts have adopted a general principle against coerced loans in bankruptcy. See Kenneth Ayotte \& David A. Skeel, Jr., Bankruptcy Law as Liquidity Provider, 80 U. CHI. L. REv. 1557, 1594-1602 (2013) (discussing the benefits and drawbacks of the coerced-loan approach).

${ }^{110}$ See generally Robert J. Stearn, Jr. \& Cory D. Kandestin, Delaware's Solvency Test: What Is It and Does It Make Sense? A Comparison of Solvency Tests Under the Bankruptcy Code and Delaware Law, 36 DEL. J. CORP. L. 165, 165-66 (2011) (describing the cash flow and balance sheet tests as they have developed under Delaware case law). 
doctrine commands a particular result-we know that the life of the law is not a logical puzzle-but rather because we think that the various doctrines at play do not preclude the sensible outcome that we think the fundamentals of administrative and corporate law permit and, indeed, favor.

We accordingly review the various doctrinal limitations in the way a lawyer would be required, while keeping an eye on the goal, which is to subject the government's regulation by deal to judicial supervision after the crisis passes, but while the government remains engaged. What follows in this Part is doctrinal; in Part III, we offer a remedy to the Fannie and Freddie puzzle that is consistent both with the doctrines and with the larger purposes of corporate and administrative law. Part III also functions as a roadmap for addressing these issues in future bailouts and the inevitable struggles among government, shareholders, and creditors which arise.

First, one must find a way around the sovereign immunity ordinarily enjoyed by the government. Assuming one can surmount the sovereign immunity hurdle, the question then becomes whether either administrative law or constitutional law provides a remedy for the government's actions in issuing the Third Amendment. Two theories emerge from traditional administrative and constitutional law; both are cited by the plaintiffs in the lawsuits against Fannie Mae and Freddie Mac over the Third Amendment. One theory is rooted in the idea that FHFA and Treasury's actions as administrative agencies exceeded their statutory authority or were otherwise arbitrary and capricious, and that, of course, the shareholders were harmed by this government action. ${ }^{11}$ The other is less worried about concerns of arbitrariness; it only asks if the Third Amendment forces shareholders to unfairly bear a burden that should be shared more generally by the taxpayers; it is rooted in the protections offered by the Constitution's Takings Clause. Neither of these approaches offers a clear path to victory, but the better view is that the administrative law claim, informed by takings law, should be upheld.

\section{Sovereign Immunity and the Conflict of Interest Exception}

The government's general exemption from suits as a sovereign except where explicitly waived creates real problems for a traditional corporate lawsuit. HERA includes succession of rights language, which means that as the

111 The arbitrary and capricious standard is codified in 5 U.S.C. $\S 706(2)$ (2012) and has been the subject of ongoing refinement. See, e.g., Motor Vehicle Mfrs. Ass'n of U.S. v. State Farm Mut. Ins. Co., 463 U.S. 29, 30-31 (1983) (holding that "arbitrary and capricious" requires the agency action to be based on a consideration of the relevant factors and whether there was a clear error of judgment); Citizens to Pres. Overton Park, Inc. v. Volpe, 401 U.S. 402, 415 (1971) (holding that arbitrary and capricious review requires a "substantial inquiry"); Ass'n of Data Processing Serv. Orgs., Inc. v. Bd. of Governors of Fed. Reserve Sys., 745 F.2d 677, 686 (D.C. Cir. 1984) (holding that arbitrary and capricious is the same as substantial evidence review). Indeed, some say arbitrary and capricious is the same as Chevron's step two. See David Zaring, Reasonable Agencies, 96 VA. L. REv. 135, 155 (2010). 
conservator of the two institutions, FHFA succeeds to all of the rights of all shareholders. ${ }^{12}$ The statute provides that FHFA, as conservator, "immediately succeed[s] to ... all rights, titles, powers, and privileges of [the company], and of any stockholder, officer, or director of [the company]."113

A suit challenging Treasury's actions is likely to be viewed as a derivative one, in the name of the corporation itself. ${ }^{114}$ The D.C. Circuit has already held that derivative actions brought on behalf of Fannie and Freddie are barred by HERA because that shareholder right was transferred to FHFA and that "absent a manifest conflict of interest by the conservator...., the statutory language bars shareholder derivative actions." 15 This rule is harsh, but presumably a similar analysis would apply even if the suit were characterized as a direct shareholder suit, given that "all rights . . of any stockholder" would include minority shareholders as well. ${ }^{116}$

While it seems quite unfair to extinguish all minority suit rights, especially when the case involves a majority shareholder acting to deliberately disadvantage the minority shareholders of Fannie and Freddie, the language of HERA is quite clear. There is a possible exception to this takeover for a "manifest conflict of interest" on the part of the conservator. ${ }^{117}$ The question would then become whether FHFA as conservator has a conflict of interest in its negotiations with Treasury-another government agency. ${ }^{118}$

112 See Kellmer v. Raines, 674 F.3d. 848, 850 (D.C. Cir. 2012) (discussing effect of HERA succession of rights language on shareholder derivative suit).

11312 U.S.C. $\S 4617(\mathrm{~b})(2)(A)(2012)$.

114 The class action complaint filed by shareholders is self-styled a derivative complaint for purposes of the fiduciary duty claims. See Shareholder Class Action Complaint, supra note 2 , at 13 .

115 Kellmer, 674 F.3d at 850 .

116 See id. (citing 12 U.S.C. $\S 4617$ (b)(2)(A)). The District Court opinion applied this rule to justify its dismissal of the plaintiffs' APA "arbitrary and capricious" claims. Perry Capital v. Lew, No. 13-CV-1053, 2014 WL 4829559, at *28-30 (D.D.C. Sept. 30, 2014) ("Such an exception would swallow the rule... . HERA provides no qualification for its bar on shareholder derivative suits, and neither will this Court." (footnote omitted)).

117 See Kellmer, 674 F.3d at 850 (recognizing that other courts have recognized a manifest conflict of interest exception to HERA's predecessor statute); see also Lubin v. Skow, 382 F. App'x 866, 871-72 (11th Cir. 2010) (suggesting that while assumption of rights language in the Financial Institutions Reform, Recovery, and Enforcement Act of 1989 ("FIRREA"), Pub. L. No. 101-73, 103 Stat. 183 (codified in scattered sections of 12 U.S.C. and 18 U.S.C.), bars derivative suits, it may not bar direct suits against officers whose actions resulted in losses to the company); First Hartford Corp. Pension Plan \& Trust v. United States, 194 F.3d 1279, 1295 (Fed. Cir. 1999) (recognizing right to bring shareholder suit where FDIC had a manifest conflict of interest); Pareto v. FDIC, 139 F.3d 696, 699-700 (9th Cir. 1998) (explaining in dicta that assumption of rights language in FIRREA would not bar suits brought by minority shareholders against majority shareholders for breach of fiduciary duty).

118 Such a claim is bolstered by the fact that the initial shares for the capital commitment scheme were created by Treasury, as was the Third Amendment. See Wind Down Press 
We believe that such a conflict exists. FHFA is an independent agency, but it acted at the behest of Treasury in its dealings with Fannie Mae and Freddie Mac. Indeed, Secretary Paulson acknowledged that the two GSEs were placed into conservatorship upon his decision, even though legally it was the head of FHFA who was given such authority. ${ }^{119}$ The related financings and other support were also coordinated out of Treasury. 120 Moreover, FHFA's mission-to preserve Fannie Mae and Freddie Mac through the financial crisis - was specifically designed to incentivize it to cater to Treasury in order to obtain necessary financing for the GSEs. ${ }^{121}$

In short, we believe the tight relationship between Treasury and FHFA itself created a conflict - namely that FHFA acted for Treasury's interests in dealings with the GSEs, not the GSEs' interests. ${ }^{122}$ Moreover, of course, the court need not conclude to a certainty that FHFA was acting on behalf of Treasury, rather than on behalf of the institutions it had seized, for a conflict of interest to appear; the appearance of a conflict is usually sufficient. Identifying a conflict, moreover, would be entirely consistent with the legal scheme created for these kinds of receivers. Under federal law, receivers of failed

Release, supra note 51; see also David Skeel, Now Uncle Sam is Ripping Off Fannie and Freddie, WALL ST. J., Feb. 28, 2014, at A13 (arguing that there must be some redress for shareholders who lost in a deal where "[t]he regulator sat on one side of the bargaining table and Treasury on the other —one arm of the government negotiating with another."); Richard A. Epstein, When Our Government Commits Fraud, DefinING IdEAS (Mar. 3, 2014), $\mathrm{http} / / / \mathrm{www}$.hoover.org/research/when-our-government-commits-fraud, archived at https://perma.cc/3ZLA-HAJ2?type=image (arguing that it "defies common sense" to bar shareholder suits and that "shutting the courtroom door to shareholders[] amounts to a per se violation of the standard procedural norms of due process").

119 Henry M. Paulson, On the Brink: Inside the Race to Stop the Collapse of the Global FinanCial System 1-6 (2011).

${ }^{120} \mathrm{Id}$. at 164-72; SORKIN, supra note 36 , at 224-27, 230-31.

121 See 12 U.S.C. $\S 4511$ (b)(2) (2012). For example, after the establishment of a conservatorship over the GSEs, the newly created FHFA director declared that it would use its authority to "ensure that the housing GSEs provide stability and liquidity to the mortgage market, support affordable housing and operate safely and soundly." Press Release, James B. Lockhart III, Director, FHFA, Fannie and Freddie Will Be Important in Economic Recovery, Lockhart Tells Realtors (Nov. 7, 2008), available at $\mathrm{http} / /$ archive.realtor.org/article/fannie-and-freddie-will-be-important-economic-recoverylockhart-tells-realtors $\% \mathrm{C} 2 \% \mathrm{AE}$.

${ }^{122}$ Delaware law supports this conclusion. In In re Oracle Corp. Derivative Litigation, 824 A.2d 917, 920-21 (Del. Ch. 2003), for example, the Delaware court held that the close ties between Oracle executives and Stanford University, exhibited by friendships and donations made to Stanford, were sufficient to establish that a conflict existed among the Oracle directors with explicit Stanford ties. This type of soft tie, which gives some incentive to a party to act at another's behest, is exactly the type of conduct at issue in the GSE litigation. 
financial institutions are required to avoid conflicts of interest like that seen here. ${ }^{123}$

A final doctrinal point will cover all of the conflict of interest bases. A more narrow view of the conflict of interest exception would not, it is worth noting, change the analysis. At common law, conflict of interests for receivers and conservators is ordinarily limited to cases where the receiver has represented one of the parties to the property. ${ }^{24}$ The courts imputing a conflict of interest exception to conservators might have been thinking of the common law tradition, even though federal statutes appear to impose broader conflict of interest obligations on receivers. But even under a cramped reading of the conflict of interest rule, the conservator, FHFA - which serves on the Treasury-chaired Financial Stability Oversight Council, and which works with Treasury on matters of systemic stability-seems deeply enmeshed in a regulatory structure headed by the department. ${ }^{125}$

If a conflict of interest exists, then a shareholder derivative suit might be pursued, at least in theory. But, for better or worse, that would not be the end of the analysis, and so we think the more systematic view looks at the conflict differently (the plaintiffs in the case would agree with us-they have brought

${ }^{123}$ For example, if the FDIC takes control of multiple firms during a crisis, it must address the potential conflicts of interest. 12 U.S.C. $\$ 5392$ (c) (2012) ("In the event that the Corporation is appointed receiver for more than 1 covered financial company or is appointed receiver for a covered financial company and receiver for any insured depository institution that is an affiliate of such covered financial company, the Corporation shall take appropriate action, as necessary to avoid any conflicts of interest that may arise in connection with multiple receiverships.").

${ }^{124}$ For example, bankruptcy trustees are obligated to avoid even a whiff of a conflict of interest created by any pre-existing relationship between them and one of the parties to the proceeding. See In re AFI Holding, Inc., 355 B.R. 139, 149 (B.A.P. 9th Cir. 2006) (describing a catch-all provision-which treats an adverse interest as material if it exists "by reason of any direct or indirect relationship to, connection with, or interest in" the debtor, or any other reason-as broad enough to exclude a trustee with some interest or relationship that "would even faintly color the independence and impartial attitude required").

${ }^{125}$ It is for these reasons that we disagree with the district court opinion on this matter which found that not only was there no conflict exception under HERA, but that even assuming one did apply, no conflict existed. Perry Capital v. Lew, No. 13-CV-1025, 2014 WL 4829559 , at ${ }^{*} 13-15$ (D.D.C. Sept. 30, 2014). The court's stated reason for finding no conflict was that the exception applied only if the investors demanded "FHFA sue itself or sue another government entity on account of FHFA's own breach." Id. at *14. Because the suits were against Treasury, and not brought by FHFA, the claim failed. Id. The court also found that Treasury and FHFA were not sufficiently "interrelated" to qualify under the Delta Savings rule because the plaintiffs were not able to point to "operational or managerial overlap" between the agencies. Id. (citing Delta Sav. Bank v. United States, 265 F.3d 1017, 1022-23 (9th Cir. 2001)). We disagree with this conclusion as we believe that FHFA and Treasury were essentially the same entity in 2012, acting in concert and at Treasury's direction. Moreover, we cannot envision a situation where the exception crafted by the court could ever apply, rendering it meaningless. 
claims under the APA and Takings Clause, and principally rely on those claims, rather than on shareholder derivative suits). If a conflict of interest exists, the amenability of the sovereign to suit is still an open question. And should a conflict, if found, mean that the right doctrinal vehicle for the suit against a federal agency is state corporate law? Because we suspect that the better approach is to look to doctrines that clearly may be applied against government agencies, we use the conflict of interest analysis outlined above to get the plaintiffs past hurdles to their suit in administrative law, and it is to these hurdles that we now turn.

\section{Arbitrariness, Unreasonableness, and the Third Amendment}

Administrative law has always been a remedy of last resort for individuals aggrieved by the conduct of the federal government. ${ }^{126}$ The problem, as a doctrinal matter, lies in the arsenal of defenses that the government enjoys against any lawsuit. ${ }^{127}$ Although the APA is the waiver of sovereign immunity of last resort, creative lawsuits against the government often run into trouble if they abandon the traditionally prescribed lines of attack. This is particularly true in challenges to actions taken by banking regulators, which are often granted wide latitude to act without judicial interference. ${ }^{128}$ But "rarely" does not mean "never." We see a doctrinal path to a remedy for the shareholders in this case, one that looks to the principles of corporate law to understand arbitrariness in the context of the government's management of an enterprise.

The first question in resolving an administrative law claim is whether the language of the statute precludes the government agencies' actions here; this is step one of the familiar two-step Chevron analysis. ${ }^{129}$ HERA gives Treasury quite broad authority in the case of a seizure of Fannie and Freddie-it need only establish that its purchase of stock is "necessary to (i) provide stability to the financial markets; (ii) prevent disruptions in the availability of mortgage finance; and (iii) protect the taxpayer." 30 HERA also requires that Treasury

\footnotetext{
${ }^{126}$ See 5 U.S.C. $\S 702$ (2012) (“A person suffering legal wrong because of agency action ... is entitled to judicial review thereof.").

${ }^{127}$ The primary bar to challenges to agency action is so-called Chevron deference, the
} doctrine that requires courts to defer to an agency's permissible construction of the authority-granting statute. Chevron U.S.A. Inc. v. Natural Res. Def. Council, Inc., 467 U.S. 837, 844-45 (1984).

${ }^{128}$ HERA is closely modeled on FIRREA, which is the statute allowing the FDIC to take over and reconstitute failed thrifts. FIRREA has been interpreted to bar most APA review. See, e.g., Freeman v. FDIC, 56 F.3d 1394, 1405-06 (D.C. Cir. 1995) (limiting homeowners challenging action of bank in FDIC receivership to the administrative remedies provided by the statute).

${ }^{129}$ Chevron, 467 U.S. at $842-43$ ("First, always, is the question whether Congress has directly spoken to the precise question at issue. If the intent of Congress is clear, that is the end of the matter; for the court, as well as the agency, must give effect to the unambiguously expressed intent of Congress.").

${ }^{130} 12$ U.S.C. $\S 1719(\mathrm{~g})(1)(\mathrm{B})(2012)$. 
consider "[ $t]$ he corporation's plan for the orderly resumption of private market funding or capital market access" and "[t]he need to maintain the corporation's status as a private shareholder-owned company" when making stock purchases. ${ }^{131}$

Nothing is forbidden by these broad considerations, nor is Treasury instructed to weigh any one of the factors particularly heavily or not. If Treasury's actions could reasonably be concluded to be consistent with the statue, then the plaintiffs would be out of luck. ${ }^{132}$

Things become even more difficult, at least as far as Chevron step one is concerned, when it turns to trying to hold FHFA accountable for its activities as a conservator (the actions of both agencies are considered because they were jointly responsible for the Third Amendment). ${ }^{133}$

HERA requires the conservator to "take such action as may be (i) necessary to put the regulated entity in a sound and solvent condition; and (ii) appropriate to carry on the business of the regulated entity and preserve and conserve the assets and property of the regulated entity." 134

The flexibility afforded here is quite large, but there are two ways that it could be limited, one of which we find persuasive.

The persuasive way looks to the agencies' broad conservatorship powers and asks whether its treatment of the GSEs violated those powers. HERA has few limitations on conservatorships (it does more for receiverships), meaning that Chevron's first step would be unlikely to constrain the agency's power to act as it wishes. However, the reasonableness of FHFA's actions would be informed by the traditional limitations on conservatorships. There, we see that agencies are given broad discretion with regard to running a business after imposing conservatorship, but limitations on the ability of a conservator to take

${ }^{131}$ Id. $\S 1719(\mathrm{~g})(1)(\mathrm{C})$.

132 See Chevron, 467 U.S. at 843 ("If, however, the court determines Congress has not directly addressed the precise question at issue, the court does not simply impose its own construction on the statute, as would be necessary in the absence of an administrative interpretation. Rather, if the statute is silent or ambiguous with respect to the specific issue, the question for the court is whether the agency's answer is based on a permissible construction of the statute." (footnote omitted)).

133 Controlling shareholders and controlling creditors are often viewed indistinctively in corporate law and bankruptcy law. See, e.g., N. Am. Catholic Educ. Programming Found., Inc. v. Gheewalla, 930 A.2d 92, 99-101 (Del. 2007) (holding that creditors may bring derivative claims when a company is insolvent, but must rely on contractual agreements, implied covenants of good faith and fair dealing, bankruptcy law, and general commercial law when the company is in the zone of insolvency). Once viewed as the product of both FHFA and Treasury, the case for judicial review becomes stronger. And there is no question that federal courts have the power to treat wrongdoing by multiple government actors with a single remedy. See, e.g., Milliken v. Bradley, 433 U.S. 267, 278-79 (1977) (approving of a remedy imposed on the city of Detroit and the state of Michigan in a school desegregation case).

13412 U.S.C. $\S 4617(b)(2)(D)$. 
actions where it has a conflict of interest or would otherwise be subject to some of the limited responsibilities imposed upon controlling shareholders under corporate law. We have outlined this argument in the prior section. As a matter of administrative law it would be covered by the so-called "hard look" that courts give agency action to make sure that the agency has explained the basis for its decision and that the decision is not being made for disallowed reasons. ${ }^{135} \mathrm{We}$ find, given that the upshot of this decision-that the government is essentially paying itself the profits--affirms that it took from private shareholders, this "disallowed reasons" analysis is the right way to think about the agencies' administrative law problems.

Less compellingly, though raised in the litigation, it is possible that when acting as a conservator, FHFA would have limited ability to wind up the corporation, which is what a receiver does. ${ }^{136} \mathrm{We}$ address this possibility because it represents a claim about what the statute requires-a Chevron step one claim-and because the plaintiffs have argued that FHFA is, indeed, purporting to act as a conservator while it actually is engaged in the liquidation of the firms.

Because the statute gives FHFA powers as both conservator and receiver, presumably, acting as one (a conservator seeking to preserve the assets of the GSEs) would preclude a sub silentio switch to acting as the other (a receiver seeking to liquidate those assets). ${ }^{137}$

The evidence supporting this allegation is quite modest. ${ }^{138}$ Fannie Mae and Freddie Mac are not paying dividends (and indeed the agreements with the

135 The canonical case announcing this general arbitrariness review is Motor Vehicle Mfrs. Ass'n v. State Farm Mut. Auto. Ins. Co., 463 U.S. 29 (2011). For a discussion, see David Zaring, Rule by Reasonableness, 63 ADMIN. L. REV. 525, 530 (2011).

${ }^{136}$ Such a reading would be based on HERA's inclusion of separate procedures and powers applicable only to FHFA when acting as a receiver. See 12 U.S.C. $\$ 4617(b)(2)$ (E) (2012) (setting out the additional powers of FHFA as receiver, requiring it to "place the regulated entity in liquidation and proceed to realize upon the assets of the regulated entity in such manner as the Agency deems appropriate").

137 We see no reason, however, why FHFA could not switch between the roles of conservator and receiver if it announced that it would be changing its role; the statute gives it the power to do both. See 12 U.S.C. $\S \S 4617($ b)(2)(D)-(E). Often conservators are appointed and then replaced by receivers when the FDIC takes over failing banks. See FDIC, RESOLUTIONS HANDBOOK 70-71 (2003), available at https://www.fdic.gov/bank/historical/reshandbook/ch7recvr.pdf (describing the FDIC's roles as conservator and receiver and explaining that the conservator's goal is to "preserve" the value of the institution, while the receiver's goal is to liquidate and distribute the assets of a "failed" institution).

138 See, e.g., Steven Davidoff Solomon, In the Markets, at Least, Fannie and Freddie Still Astound, N.Y. Times DeALBOoK (Apr. 9, 2013, 9:26 PM), http://dealbook.nytimes.com/2013/04/09/in-the-markets-at-least-fannie-and-freddie-stillastound, archived at $\mathrm{http} / / /$ perma.cc/8XHE-3SNE (discussing continuing presence of Fannie Mae in the market despite conservatorship); see also Who is Fannie Mae Today, FANNIEMAE (Nov. 6, 2014), http://www.fanniemae.com/portal/about-us/company- 
government can be read to forbid them in perpetuity from paying dividends), but many companies do not pay dividends. ${ }^{139}$ The failure to do so hardly means that they are in the process of being wound up. Berkshire Hathaway has famously never paid a dividend and it is very much a going concern. ${ }^{140}$ And

overview/about-fm.html, archived at https://perma.cc/C5GN-LPWF?type=image ("As the leading source of residential mortgage credit in the U.S. secondary market, Fannie Mae is supporting today's economic recovery and helping to build a sustainable housing finance system.").

139 The purchase agreements for the government preferred shares forbid the payment of a dividend without Treasury's consent. See U.S. Dep't of the Treasury \& Fed. Nat'l Mortg. Ass'n, Amended and Restated Senior Preferred Stock Purchase Agreement at $\S 5.1$ [hereinafter Fannie Mae Stock Purchase Agreement]; U.S. Dep't of the Treasury \& Fed. Home Loan Ass'n, Amended and Restated Senior Preferred Stock Purchase Agreement at $\S$ 5.1 [hereinafter Freddie Mac Stock Purchase Agreement]. The preferred shares thus would need to be redeemed or repurchased for a dividend to be paid without government consent. However, the provision for redemption in the stock certificate for the Treasury preferred shares only permits optional redemption if there is a "termination of the Commitment." Fed. Nat'1 Mortg. Ass'n Certificate of Designation of Terms of Variable Liquidation Preferences Senior Preferred Stock, Series 2008-2, at § 3(a) [hereinafter Fannie Mae Treasury Stock Certificate]; Fed. Home Loan Mortg. Ass'n, Treasury Stock Certificate at §3(a) [hereinafter Freddie Mac Treasury Stock Certificate]. The certificate then states that "Commitment" is defined in the share purchase agreement. See Fannie Mae Stock Purchase Agreement at $\S$ 2.1; Freddie Mac Stock Purchase Agreement at $\S 2.1$. The Share Purchase Agreements state that the "Commitment shall terminate" upon the earliest of:

(a) if the Liquidation End Date shall have occurred, (i) the payment in full of Purchaser's obligations with respect to any valid request for funds pursuant to Section 2.4 or (ii) if there is no Deficiency Amount on the Liquidation End Date or if no such request pursuant to Section 2.4 has been made, the close of business on the 15th Business Day following the determination of the Deficiency Amount, if any, as of the Liquidation End Date; (b) the payment in full of, defeasance of or other reasonable provision for all liabilities of Seller, whether or not contingent, including payment of any amounts that may become payable on, or expiry of or other provision for, all Mortgage Guarantee Obligations and provision for unmatured debts; and (c) the funding by Purchaser under the Commitment of an aggregate of $\$ 100,000,000,000$ (one hundred billion dollars).

Fannie Mae Stock Purchase Agreement at $\S 2.5$.

One reading of this clause is that the commitment only terminates if the GSE is liquidated or the commitment is completely drawn down. If so, then the government would be able to have a negative say on a dividend in perpetuity. See John Carney, Snatching Defeat from Victory at Frannie, WALL ST. J., Aug. 18, 2014, at C6. Nonetheless, the agreements were not designed to deal with the survival of Fannie Mae and Freddie Mac, and there is some ambiguity as to when the commitment terminates for purposes of the stock certificates-is it instead when it is no longer needed? We believe that there is sufficient uncertainty to sustain a litigation claim over the matter. In any event, even if a dividend is never paid, cash would build up at the GSEs and there would be value for the junior and common shares in a liquidation. The market would likely attribute value to this claim.

140 Warren Buffett-Why Berkshire Will Never Pay Dividends, YouTuBE (May 12, 2011), https://www.youtube.com/watch? $v=\mathrm{aL} 766 \mathrm{NK} 2 \mathrm{ynw} \&$ feature=youtu.be $\& \mathrm{t}=2 \mathrm{~m} 28 \mathrm{~s}$. 
eventually, enough cash would build up that steps would likely have to be taken or a liquidation of the firm would become quite profitable for the common and junior holders. For now, though, Fannie and Freddie have not been dismembered and sold off in parts; indeed, they still remain important players in the mortgage market. Although the government has endeavored to shrink the businesses, they are still enormous, and nothing precludes a conservator from pursuing a more modest business plan than the one pursued before the company being conserved collapsed.

Indeed, this broad flexibility afforded conservators would seem to explicitly authorize them to reduce the size of a business they took over. HERA, after all, permits appointment as "conservator or receiver for the purpose of reorganizing, rehabilitating, or winding up."141

\section{Issues of Remedy and Administrative Law}

If the shareholders were able to get past the jurisdictional issues and reach the merits, there is an additional issue of whether a court would actually be able to provide a remedy. The two doctrinal hurdles posed here are, first, the hurdle posed by the anti-injunction provisions of HERA, and second, the general remedial preference, as the APA has been interpreted, in favor of remand to the agency; in this case, these hurdles could conceivably mean remand to Treasury and FHFA to negotiate a more arms-length agreement with one another about what to do about the remaining minority shareholders. We believe that the anti-injunction problem and the remand preference can be avoided by a specific judicial opinion: one that does not require Treasury and FHFA to adopt an entire fairness review, but one that makes it clear that an entire fairness analysis is the way to avoid a finding of arbitrariness.

This sort of recommendation is required in light of HERA's bar against more directive relief. HERA provides that "no court may take any action to restrain or affect the exercise of powers or functions of the agency as a conservator." 142 The D.C. Circuit interpreted an identical provision in FIRREA to bar any court review of a receiver's actions, and, indeed, as a general matter, courts do not review receiver actions for arbitrariness and capriciousness despite the fact that the receivers are acting on the government's behalf. ${ }^{143}$ Several other courts of appeals have construed the HERA provisions similarly to this provision and held that it bars any review of FHFA's actions in its statutorily defined role as conservator. ${ }^{144}$

\footnotetext{
14112 U.S.C. $\S 4617(a)(2)$ (2012).

${ }^{142}$ Id. $\S 4617(\mathrm{f})$.

${ }^{143}$ Freeman v. FDIC, 56 F.3d 1394, 1399 (D.C. Cir. 1995) (holding that the provision "effect[s] a sweeping ouster of courts' power to grant equitable remedies").

${ }_{144}$ See Cnty. of Sonoma v. FHFA, 710 F.3d 987, $992-93$ (9th Cir. 2013) (holding that there was no APA review available to challenge FHFA's decision not to purchase certain mortgages); Leon Cnty., Fla. v. FHFA, 700 F.3d 1273, 1278-79 (1 Ith Cir. 2012) (holding no APA review because FHFA's decision not to purchase mortgages was within its role as
} 
The problem for the courts posed by this anti-injunction provision is that any remedy for arbitrariness under the APA is, essentially, an injunctive one. The APA forbids the award of monetary damages and generally requires, in cases featuring a successful challenge, a direction to the agency-something that sounds quite like injunctive relief. ${ }^{145}$

These cases hold, however, that the bar on judicial review applies only when FHFA is acting within its statutory authority, thus, the question of whether or not the Third Amendment is within FHFA and Treasury's HERA authority, discussed above, likely decides the fate of plaintiffs' remaining claims. ${ }^{146}$ As the Ninth Circuit has said, "FHFA cannot evade judicial review ... simply by invoking its authority as conservator." 147

Moreover, just as a clear conflict of interest offers a way to get around the government conservator's sovereign immunity defense, so does it too, for the same reasons, offer a way for courts to get around an anti-injunction provision. The idea is that when a conflicted conservator forfeits its ordinary protections against suit, the conservator also forfeits its special protections from injunctive relief. The recent district court opinion rejected any such exception for APA review, holding that the bar was intended to be absolute. ${ }^{148}$ The district court also rejected any conflict of interest review for derivative claims. ${ }^{149}$ The court

conservator and not "regulator"); Town of Babylon v. FHFA, 699 F.3d 221, 228 (2d Cir. 2012) ("A conclusion that the challenged acts were directed to an institution in conservatorship and within the powers given to the conservator ends the inquiry.").

145 Monetary damages for contract claims must be brought in the Court of Federal Claims pursuant to the Tucker Act. ch. 359, 24 Stat. 505 (1887) (codified as amended at 28 U.S.C. $§ 1491(a)(1)(2012)$ ). To the extent that the shareholders' claims might be construed as contract claims (and preferred shareholders arguably have a contract encapsulated by their shares, which gives them a specific rate of return akin to a debt contract), one might argue (and the government has argued) that their claims should be brought in that court. Because we think that this claim should be resolved in the same way as the claim alleging a bar on APA claims, we refer our readers to notes 146-161 and the accompanying text in this section of the article.

${ }^{146}$ See Leon Cnty., 700 F.3d at 1278 ("The FHFA cannot evade judicial scrutiny by merely labeling its actions with a conservator stamp."); Town of Babylon, 699 F.3d at 22728 (suggesting that APA review might be available when FHFA acts within its regulatory rulemaking authority); see also MBIA Ins. Corp. v. FDIC, 708 F.3d 234, 247 (D.C. Cir. 2013) (holding in FIRREA case that the anti-injunction provision "does not bar injunctive relief when the FDIC has acted or proposes to act beyond, or contrary to, its statutorily prescribed, constitutionally permitted, powers or functions").

147 Cnty. of Sonoma, 710 F.3d at 994; see also Leon Cnty., 700 F.3d at 1278 ("The FHFA cannot evade judicial scrutiny by merely labeling its actions with a conservator stamp.").

148 Perry Capital v. Lew, No. 13-CV-1025, 2014 WL 4829559, at *6 (D.D.C. Sept. 30, 2014) (holding that HERA's anti-injunction provision was a "sweeping ouster" of any judicial review (quoting Freeman v. FDIC, 56 F.3d 1394, 1399 (D.C. Cir. 1995))).

${ }^{149}$ Id. at ${ }^{*} 13$ ("It strikes this Court as odd that a statute like HERA, through which Congress grants immense discretionary power to the conservator and prohibits courts from interfering with the exercise of such power would still house an implicit end-run around 
decided that any attempt to determine whether or not FHFA and Treasury exceeded their statutory review would inevitably collapse into judicial review of the merits of and rationale for agency action, thereby defeating the purpose of the injunction bar. ${ }^{150}$

We think that such a reading, whatever its bright-line merits, treads too much into non-justiciability. Taken seriously, it means that the anti-injunction provision bars any and all review of a banking regulators' actions under statutes like HERA and FIRREA, an approach already rejected by other federal courts of appeals. ${ }^{151}$ Below, we identify a middle ground that the district court declined to consider, between no judicial review and merits review of agency action in all cases. The remedy need not amount to an injunctive directive that would traduce Congress's intent that conservators not be at risk of being stymied by an injunction (the worry - not present in the case against Fannie and Freddie - is that a judicial decree could slow, and thereby endanger, the prospect of a quick resolution of a failing financial institution).

A court could, for example, write an opinion consistent with the principle that the preferred remedy available under the APA is remand to the agency, and nonetheless offer substantial direction. ${ }^{152}$

After all, there is remand, and then there are other kinds of remand. Some administrative law remedies depart from remand in quite specific ways. In the well-known and lengthy Cobell Indian trust litigation, the plaintiffs asked for nothing more than an "equitable accounting" of moneys held in trust by the government for various Indian tribes, although what they sought (and what the trial court awarded, in the end) was money provided through this equitable accounting rubric. ${ }^{153}$ The D.C. Circuit has held that it has jurisdiction under the APA to issue an injunction blocking FDIC's appointment of a receiver for a failed bank under FIRREA. ${ }^{154}$ In James Madison Ltd. v. Ludwig, ${ }^{155}$ the court reviewed the agency's appointment of the receiver and contemplated granting

FHFA's conservatorship authority ...." (citations omitted)).

${ }^{150} \mathrm{Id}$. at *10 ("Requiring the Court to evaluate the merits of FHFA's decisionmaking each time it considers HERA's jurisdictional bar would render the anti-injunction provision hollow . . . "). Note that there is nothing in our approach that would require evaluation of the merits each time the court considers HERA's jurisdictional bar as such review would only be required when the plaintiff could plausibly plead a conflict of interest.

151 See, e.g., supra note 146.

152 Palisades Gen. Hosp. Inc. v. Leavitt, 426 F.3d 400, 403 (D.C. Cir. 2005) ("[U]nder settled principles of administrative law, when a court reviewing agency action determines that an agency made an error of law, the court's inquiry is at an end: the case must be remanded to the agency for further action consistent with the correct legal standards." (internal quotation marks omitted)).

153 Cobell v. Norton, 240 F.3d 1081, 1086 (D.C. Cir. 2001) ("The relief ordered was well within the district court's equitable powers.").

154 James Madison Ltd. v. Ludwig, 82 F.3d 1085, 1092 (D.C. Cir. 1996).

$155 \mathrm{Id}$. 
injunctive relief against the agency, rejecting the argument that the antiinjunction provision applied. ${ }^{156}$

As a general matter, of course, injunctions are available in the court's discretion when legal remedies, such as statutory review, are not available or adequate. ${ }^{157}$ To be sure, injunctive relief is only available when the plaintiff establishes irreparable harm and, when to prevent unlawful official conduct, the court determines that the conduct will continue without the injunction. ${ }^{158}$ But there is a good case to be made that these requirements could inform a judicial opinion, making clear that, upon remand, the best way to ensure compliance with the APA would be to adopt a freeze-out on terms that would meet an entire fairness test.

In Part III we provide a roadmap for navigating these doctrinal hurdles.

\section{Constitutional Issues and the Takings Clause}

A second way to discipline agency overreaching in the wake of a financial crisis is to use the Takings Clause to provide monetary damages to those who have been injured disproportionately by the government's action. The Takings Clause has been used before to discipline the government for bad behavior after taking over financial institutions-the way it handled many of the thrifts takeovers during the savings and loan crisis of the 1980s led to the largest damage awards against the government that had ever been seen. ${ }^{159}$ Takings law also supports claims where, after the government takes over a financial institution, it is presented with a conflict of interest with regard to its treatment of other shareholders. Although we prefer an administrative law remedy to a takings remedy, we do not prefer it particularly strongly. The sort of unfairness that the Takings Clause is meant to police when it comes to the takeover of a financial firm helps inform the sort of equitable inquiry a court might make in evaluating the government's case under the APA. In that sense, we think that good policy might be vindicated if a court found a remedy under either the APA or the Takings Clause. ${ }^{160}$

156 Id. ("We thus read section 1821(j) to prevent courts from interfering with the FDIC only when the agency acts within the scope of its authorized powers, not when the agency was improperly appointed in the first place.").

1573 Richard J. Pierce, JR., Administrative LaW Treatise $\$ 18.4$, at 1701 (5th ed. 2010) ("[l]njunctions have become the most common nonstatutory remed[y] for unlawful agency action.").

$158 \mathrm{Id}$.

159 See, e.g., U.S. Gov't ACCOUNTABILITy OfFICE, GAO-10-705, FInANCIAL Audit: FEDERAL DEPOSIT INSURANCE CORPORATION FUNDS' 2009 AND 2008 FinANCIAL STATEMENTS 54-59 (2010), available at http://www.gao.gov/assets/310/306103.pdf, (totaling government liability from just four 2009 Winstar claims cases at $\$ 405.4$ million).

160 Hanoch Dagan has argued that the Takings Clause is particularly appropriately invoked in these sorts of government appropriations. See Hanoch Dagan, Expropriatory Compensation, Distributive Justice, and the Rule of Law, available at http://papers.ssm.com/sol3/papers.cfm?abstract_id=2345115 (examining "the possible 
The case for a taking is plausible: the character of the government action is severe, its economic impact, from the perspectives of the shareholders, is awesome, and their investment-backed expectations-their shares-are, of course, threatened with the loss of all economic value, if that value is calculated in the traditional manner, based on the projected revenue scheme of the asset. ${ }^{161}$ Diverting expected dividends from common and preferred shareholders to Treasury might seem like a particularly obvious form of taking.

Because of this, some Fannie Mae and Freddie Mac shareholders have filed takings claims. ${ }^{162}$ Just as with the APA, the Takings Clause claim is not without its own set of doctrinal hurdles to overcome; we review those here.

In cases where a regulatory scheme does not involve a physical invasion or occupation of property, the Supreme Court "has generally 'been unable to develop any 'set formula' for determining when 'justice and fairness' require that economic injuries caused by public action" result in a compensable taking. ${ }^{163}$ The Court, however, has identified three factors to consider when determining whether a governmental action has exceeded "regulation" to become a "taking." Those factors are "the character of the governmental action, its economic impact, and its interference with reasonable investmentbacked expectations." 164

Banks, as institutions rather like the GSEs, have never had much luck arguing that seizures of their assets via the FDIC's resolution authority implicate the Takings Clause. ${ }^{165}$ Although the doctrine covers banks, the

justification for providing less than full (fair market value) compensation for expropriation"). Nestor Davidson has argued, on the other hand, that government bank seizures in the middle of an economic emergency should not be subject to takings liability, on the assumption that the situation is similar to cases where the fire department knocks down buildings to halt a conflagration. See generally Nestor M. Davidson, Nationalization and Necessity: Takings and a Doctrine of Economic Emergency, 3 BRIGHAM-KANNER PROP. RTS. CONF. J. 187 (2014).

${ }^{161}$ See Shiller, supra note 54; see also Donald C. Clarke, Three Concepts of the Independent Director, 32 DEL. J. CORP. L.73, 91-92 n.70 (2007) ("[T] he share price at any given time reflects the market's best guess as to the discounted present value of all income (not just income over the short term) that can be earned by the share, whether through dividends or ultimate sale.").

162 See, e.g., Fairholme Funds Complaint, supra note 2.

${ }^{163}$ Kaiser Aetna v. United States, 444 U.S. 164, 175 (1979) (quoting Penn Cent. Transp. Co. v. City of New York, 438 U.S. 104, 124 (1978)); accord Hodel v. Va. Surface Mining \& Reclamation Ass'n, 452 U.S. 264, 295-96 (1981) (applying the "economically viable use" test in determining the existence of a regulatory taking).

164 PruneYard Shopping Ctr. v. Robins, 447 U.S. 74, 83 (1980).

165 See FDIC v. Mallen, 486 U.S. 230, 242 (1988) (holding that the Takings Clause applies to banks, although it was not implicated by the resolution powers of the FDIC, given the highly regulated nature of the banking industry); Bd. of Governors of Fed. Reserve Sys. v. DLG Fin. Corp., 29 F.3d 993, 1001-02 (5th Cir. 1994) (using the Mallen factors to evaluate the sufficiency of due process in an FDIC takeover). 
Federal Circuit has held that "[g]iven the highly regulated nature of the banking industry, ... the [federal regulators' seizure of the bank] could not possibly have interfered with a reasonable investment-backed expectation on the part of [the owners of a bank]." 66 Accordingly, "[t]he Federal Circuit has never upheld a claim that a seizure of a financial institution under the statutes and regulations designed to insure safe and secure banking institutions constituted a taking."167

Nonetheless, in First Hartford Court Pension Plan and Trust v. United States, ${ }^{168}$ the Federal Circuit held that the shareholders of the failed thrift might be able to raise a takings claim against the FDIC if, after the thrift passed through receivership and was reconstituted, there was money left over in the corporate shell of the original thrift. ${ }^{169}$ Critically, the court in First Hartford held not only that the shareholders had standing, but also that they could proceed despite the FDIC's assumption of all of the shareholders rights because of the FDIC's manifest conflict of interest and refusal to sue. ${ }^{170}$

The concern is that a government agency sitting as a manager of a failed firm like the GSEs might have a conflict of interest in making the decision whether to return any funds to shareholders instead of keeping those funds for itself. Thus, the Federal Circuit held that a takings claim might be appropriate on behalf of shareholders because "the FDIC was asked to decide on behalf of the depository institution in receivership whether it should sue the federal government based upon a breach of contract which, if proven, was caused by the FDIC itself." 171

Alternatively, the government's abrogation of agreements can form the basis of a taking. Most expensively, it did so in the Winstar lawsuits brought by the acquirers of failed thrifts that had, as an incentive to make the purchase, entered into supervisory action agreements with the thrift regulator that promised them lenient regulatory treatment. ${ }^{172}$ When Congress made the use of these sorts of agreements illegal, a plurality of the Supreme Court held that the government had taken thrift property - that is, the benefit of the agreementwithout compensation. ${ }^{173}$ In addition, the plurality in Winstar found that

\footnotetext{
166 Golden Pac. Bancorp v. United States, 15 F.3d 1066, 1074 (Fed. Cir. 1994).

167 Franklin Sav. Corp. v. United States, 46 Fed. Cl. 533, 535 (2000), aff'd, 97 F. App'x 331 (Fed. Cir. 2004).

168194 F.3d 1279 (Fed. Cir. 1999).

$169 \mathrm{Id}$. at $1287-88$.

${ }^{170} \mathrm{Id}$. at 1295 ("First Hartford submitted multiple requests to the FDIC to bring suit, but received responses merely indicating that the FDIC was continuing to consider the matter.").

$171 \mathrm{Id}$.

172 United States v. Winstar Corp., 518 U.S. 839, 848 (1996) ("[T]he principal inducement for these supervisory mergers was an understanding that the acquisitions would be subject to a particular accounting treatment that would help the acquiring institutions meet their reserve capital requirements imposed by federal regulations.").

173 Id. at 910 (affirming the "Federal Circuit's ruling that the United States is liable to
} 
sovereign immunity did not apply to contract claims in situations where the government acted not as a sovereign, but as a contract counterparty. ${ }^{174}$

The Takings Clause thus provides two litigable paths forward for the Fannie and Freddie plaintiffs. For a Winstar-like claim, the shareholders might analogize whatever contractual rights are provided by the shares held by Fannie and Freddie's minority shareholders to the deal entered into by thrift regulators and reneged by Congress. ${ }^{175}$ The fit is not easy; in one case, the government entered into an explicit arrangement with thrift investors, while in the other, the government merely took control of a corporation that might have had pre-existing, contractually created rights to a dividend in its shares.

The other path requires the plaintiffs to establish that, after the receivership, the government has a strong conflict of interest. It can pay a dividend to other shareholders or keep all the profits for itself. In this way, it chooses between using the expected returns from its valuable property to feather its own nest or to compensate plaintiffs. The government has every incentive to reject the plaintiffs' petition, putting it into the position, unloved in due process, of referee and competitor in the same game. ${ }^{176}$

Both approaches illustrate two critical issues that we believe inform the remedy the court could adopt. First, they depend on the claim that the property taken from the shareholders is property of value. ${ }^{177}$ This boils down to whether Fannie and Freddie had any worth at the time of the Third Amendment.

respondents for breach of contract").

${ }^{174} \mathrm{Id}$. at $887-88$ ("[T]he Government agreed to do something that did not implicate its sovereign powers at all, that is, to indemnify its contracting partners against financial losses arising from regulatory change.").

${ }^{175} C f$. United States Trust Co. of New York v. New Jersey, 431 U.S. 1, 19 n.16 (1977) ("Contract rights are a form of property and as such may be taken for a public purposes provided that just compensation is paid.").

176 The D.C. Circuit initially held that the fact that agencies act in their own self-interest does not merit Chevron deference, but recently held that that this fact does not, by itself, preclude it deference. See Indep. Petroleum Ass'n of Am. v. DeWitt, 279 F.3d 1036, 1040 (D.C. Cir. 2002); Indiana Michigan Power Co. v. Dep't of Energy, 88 F.3d 1272, 1276 (D.C. Cir. 1996) (holding that the Department of Energy's interpretation of the Nuclear Waste Policy Act of 1982 did not warrant Chevron deference and failed Chevron step one because the agency interpreted it to exculpate itself from disposing of waste specified in a contract the agency made); Nat'l Fuel Gas Supply Corp. v. F.E.R.C., 811 F.2d 1563, 1571 (D.C. Cir. 1987) ("There may, of course, be circumstances in which deference would be inappropriate... . [I]f the agency itself were an interested party to the agreement, deference might lead a court to endorse self-serving views that an agency might offer in a post hoc reinterpretation of its contract."); see generally Timothy K. Armstrong, Chevron Deference and Agency Self-Interest, 13 CoRnell J. L. \& PUB. POL'Y 203 (2004) (providing an overview of how courts have dealt with self-interest under Chevron).

177 See Penn Cent. Transp. Co. v. City of New York, 438 U.S. 104, 124 (1978) (listing the "economic impact of the regulation" as a factor in finding a taking); see also Brown v. Legal Found. of Wash., 538 U.S. 216, 240 n.11 (2003) ("[J]ust compensation for a net loss of zero is zero."). 
Second, they depend on government action that looks like clear chicanery. The regulators in Winstar may not have been cynical opportunists, but Congress forced them to essentially lure investors into thrifts with written promises that they later broke. The receiver in First Hartford also had a clear conflict of interest created by being a judge in its own case. ${ }^{178}$

As we suggest below, we think this sense of unfairness animates this sort of creative litigation. Although we marginally prefer an administrative law remedy to a Takings Clause remedy (our interest in disciplining the government in a way that still affords it the flexibility to act in a crisis would also be met with a takings remedy), we find that the rare occasions in which takings cases have been permitted in receivership cases inform our administrative law analysis. Indeed, the fact that the bulk of plaintiffs' claims in these suits focus on APA defects shows where they believe their strongest case lies.

\section{SOLVING FANNIE AND FREDDIE}

In the prior section, we reviewed the various doctrines at play in a case where administrative law and corporate law meet. As we have shown, these doctrines do not pose insurmountable hurdles to a remedy; in this section of the Article, we offer the path forward that we believe should govern the resolution of the shareholders' claims.

\section{A. Discipline Through the APA}

A court can get to the point under the APA where a remedy is appropriate by using the usual Chevron two-step test, under which a government agency's

${ }^{178}$ Regardless, we believe that the district court's finding that the Takings Clause was not violated by the Third Amendment is flawed. The court based its approach on the fact that these GSEs were highly regulated. It concluded that because banking is heavily regulated, the regulation provides the right to seize the firm. Applying this reasoning to the GSEs, the court concluded that Fannie and Freddie's investors possessed no property interest following imposition of the conservatorship. Perry Capital LLC v. Lew, No. CV 131025 (RCL), 2014 WL 4829559, at *22 (D.D.C. Sept. 30, 2014). The court found that by consenting to invest in a highly regulated industry, shareholders had also consented to the possible extinguishment of their rights pursuant to that statutory scheme. Id. This essentially meant that investors in these banks could never have standing for a takings claim following the imposition of a conservatorship, let alone in this case.

We believe this misunderstands the bargain between shareholders and the government. Shareholders could be understood to have agreed to the regulation and the possibility of conservatorship, yet they also had the right to assume that the government would abide by those regulations with respect to their property, creating a colorable constitutional claim, as we outline above. This seems particularly relevant in the conservatorship context, which, unlike a receivership, aims to preserve the existence of the privately held corporation. Moreover, the government should not be immunized from the restraints imposed by the Takings Clause solely because it observed the right procedural niceties in the first step of a taking. 
action is reviewed for unreasonableness. ${ }^{179}$ As we have observed, from a doctrinal perspective, administrative law is the broadest vehicle for dealing with arbitrary government action, and, as an injunctive doctrine (the remedy for takings cases is cash from the government), it fits well with the fiduciary requirements of corporate law, which also tend to result in injunctive relief. ${ }^{180}$

Under step two of the Chevron test, which reviews agency action for its reasonableness, or under the general arbitrariness review that courts must finally accord agency action (one of us has argued that, whatever the state of the doctrine now, there is little difference between the inquiry as to whether the government acted unreasonably and whether it acted arbitrarily ${ }^{181}$ ), we see a way to discipline the government, and to provide the plaintiffs with a modest reward for doing so.

As an initial matter, it is worth emphasizing that the government action being reviewed here is not the decision to take over both Fannie and Freddie. Nor is it even the part of the takeover that left a $20.1 \%$ equity interest of the company in private hands. Instead, the question here is what to do about the Third Amendment. The action being tested is Treasury's agreement with FHFA to change the dividend policy from a Treasury-takes-first-ten-percent dividend to one in which Treasury takes all profits from the company over and above a sufficient capital buffer. This, in sum, is not a case where the difficult choices the government had to make in the midst of the financial crisis are being tested; it is instead a case involving the question of how to evaluate the government's actions well after the crisis period had passed. As we have observed, HERA's plain language likely does not preclude either Treasury or FHFA from interpreting their powers to include the sort of takeover made initially or even changing the dividend policy. ${ }^{182}$ That language is broad enough for doctrinalists interested in plain language constraints (or the lack thereof) provided by statutes. Moreover, it exists in a context of deference; courts usually avoid reviewing conservators' actions as they are uninterested in being in the business of second guessing managerial decisions over a business entity. ${ }^{183}$ And, of course, the resolution powers offered in HERA and FIRREA require courts to be quite deferential.

179 See supra note 132 and accompanying text.

180 See generally 12 FLETCHER, supra note 80 , at $\$ 5419$ (explaining that under corporate law, injunctive relief is granted to investors when dividends are not distributed according to the law).

181 See Zaring, supra note 111 and accompanying text.

182 See supra note 37.

18312 U.S.C. $\$ 4617$ (b)(2)(D) (2012) ("The Agency may, as conservator, take such action as may be-- (i) necessary to put the regulated entity in a sound and solvent condition; and (ii) appropriate to carry on the business of the regulated entity and preserve and conserve the assets and property of the regulated entity."). But see Coleman, supra note 28, at 521 (arguing that the net worth sweep would fail under the Chevron test because HERA would only allow that as a receivership, not a conservatorship). 
Nonetheless, government actions that fall within the ambiguously broad grant of authority of a statute may nonetheless still be arbitrary and capricious; this is hard look review (or, some lawyers might argue, Chevron's second step). ${ }^{184}$ There is usually a bar to review of a conservator's actions under HERA, but that bar would not apply if the conservator is acting with a conflict of interest-as both First Hartford, in the takings context, and Kellmer, in the context of administrative law, provide. Moreover, as we have observed, the conflict of interest here is remarkable.

It is fair to conclude that a controlling shareholder's decision to award all of the profits of a company to itself is a self-dealing transaction, and it is this sort of bad faith that courts have suggested provides a reason to look beyond the bars of review that ordinarily exist in receivership and conservatorship cases. ${ }^{185}$ For example, decisions by the FDIC on the way it has timed the repudiation of contracts in failed banks have been policed by the courts on a number of metrics, including evidence of bad faith by the receiver. ${ }^{186}$ Indeed, one of the reasons to appoint a receiver is to take over an enterprise that has been acting in bad faith; it would be odd to assume that if the receiver also exhibited bad faith, the court could do nothing about it. ${ }^{187}$

184 See, e.g., Nat'l Credit Union Admin. v. First Nat. Bank \& Trust Co., 522 U.S. 479, 500 (1998) (holding that National Credit Union's interpretation of the statute was not reasonable because Congress had spoken directly on the issue). Scholars have argued that Chevron step one and two are actually the same, i.e., under step two, the court asks if the statute could be interpreted through standard means of statutory interpretation. However, if it can, that means that Congress has spoken on the issue. See Matthew C. Stephenson \& Adrian Vermeule, Chevron Has Only One Step, 95 VA. L. Rev. 597, 599 (2009) ("If an agency's construction of the statute is 'contrary to clear congressional intent . . . on the precise question at issue,' then the agency's construction is a fortiori not 'based on a permissible construction of the statute.' Step One is therefore nothing more than a special case of Step Two, which implies that all Step One opinions could be written in the language of Step Two."). For our purposes, however, we will follow the ABA guidelines that suggest that Chevron step two is the same as arbitrary and capricious review. See Zaring, supra note 111.

185 See, e.g., Kahn v. Tremont Corp., 694 A.2d 422, 428-29 (Del. 1997) (applying fairness review to transaction where the controlling shareholder of a corporation caused the company to purchase shares of a corporation controlled by the same shareholder); Weinberger v. UOP, Inc., 457 A.2d 701, 710 (Del. 1983) ("The requirement of fairness is unflinching in its demand that where one stands on both sides of a transaction, he has the burden of establishing its entire fairness, sufficient to pass the test of careful scrutiny by the courts.").

186 See, e.g., Cent. Buffalo Project Corp. v. FDIC, 29 F. Supp. 2d 164, 170 (W.D.N.Y. 1998); Monument Square Assocs., Inc. v. Resolution Trust Corp., 792 F. Supp. 874, 879 (D. Mass. 1991). For a discussion of these cases, see Erin Burrows \& F. John Podvin, Jr., Revisiting the FDIC's "Superpowers": Contract Repudiation and D'Oench Duhme, 127 BANKING L. J. 395, 400 (2010).

187 See, e.g., Judge Rotenberg Educ. Ctr., Inc. v. Comm'r of the Dep't of Mental Retardation, 677 N.E.2d 127, 150 (Mass. 1997) (“'A]ppointing a receiver to restore legality 
By the same token, the broad authority to protect taxpayers and provide stability to the financial markets cannot be said to reasonably include the pursuit of corporate shenanigans that never would be accepted in Delaware courts of equity at the federal level. ${ }^{188}$ Government corporations, for example, are often thought to have fiduciary obligations. ${ }^{189}$ Government trusts have the same sorts of rules. For example, in an Indian law case, the Supreme Court held that:

[W] here the Federal Government takes on or has control or supervision over tribal monies or properties, the fiduciary relationship normally exists with respect to such monies or properties (unless Congress has provided otherwise) even though nothing is said expressly in the authorizing or underlying statute (or other fundamental document) about a trust fund, or a trust or fiduciary connection. ${ }^{190}$

The economic basis of these fiduciary duties is rooted in classic governmental principles of trust and integrity. Shareholders provide funds to corporate entities knowing that corporate rules will prevent fiduciaries from taking undue advantage of their trust. ${ }^{191}$ This bedrock principle of corporate law is designed to engender more optimal economic outcomes and provide avenues for acceptable capital-raising. The rules of entire fairness are part and parcel of this package, designed to protect minority shareholders from oppression and accompanying uneconomic outcomes. In the government setting, the rule of law serves similar republican purposes. More specifically, here the government has raised capital from private investors to further its aims. Beyond simple rule of law issues, we see no reason why the ordinary rules for corporations should not apply given the government's seeming precommitment to abide by these rules-rules which have solid economic foundation.

to a State agency which has failed, over a long period of time, to comply with [a] settlement agreement and abused its regulatory authority by acting in bad faith, does not derogate the separation principle.").

188 See, e.g., In re Walt Disney Co. Derivative Litig., 906 A.2d 27, 67 (Del. 2006) (holding that a breach of good faith can be shown "where the fiduciary intentionally acts with a purpose other than that of advancing the best interests of the corporation").

189 See Michael J. Whincop, Another Side of Accountability: The Fiduciary Concept and Rent-seeking in Government Corporations, SOCIAL SCIENCE RESEARCH NETWORK 11-16 (Nov. 2000), available at http://papers.ssm.com/paper.taf?abstract_id $=258668$ (discussing the fiduciary obligations and relationships underlying the accountability of government corporations).

190 United States v. Mitchell, 463 U.S. 206, 225 (1983) (quoting Navajo Tribe of Indians v. United States, 624 F.2d 981, 987 (1980)).

191 See Guth v. Loft, Inc., 5 A.2d 503, 510 (Del. Ch. 1939) ("Corporate officers and directors are not permitted to use their position of trust and confidence to further their private interests ... . The rule that requires an undivided an unselfish loyalty to the corporation demands that there shall be no conflict between duty and self-interest."). 
The government could have liquidated or fully nationalized the GSEs during the financial crisis. It did not do so. The government thus made its choice to put the GSEs into conservatorship and should not be allowed, outside a crisis situation, to simply abrogate its pre-commitment. While the government may not soon move to raise private capital for public corporations again, certainly its commitment to law is priced in its debt and other obligations. A readherence to law therefore minimizes the adverse general social welfare effects of necessary action taken during the financial crisis.

Finally, it makes sense for administrative law to look to the basic principles of corporate governance in determining what counts as reasonable conduct when the controlling shareholder is the government. Indeed, as Evan Criddle has argued, "paradigmatic fiduciary relations such as trust, guardianship, and corporation may serve as useful alternative paradigms for independent agencies, government corporations, and other administrative institutions." 192

The entire fairness rule here does something further in terms of government conduct. Entire fairness is an economic rule designed to protect minority or dissenting shareholders in certain circumstances. It is a subset of fiduciary duties designed to protect shareholders and govern their relationships with management. By employing entire fairness and fiduciary duty principles in an administrative review of this type, a court would simply be incorporating similar principles embedded within the Due Process Clause and the limitations of the Takings Clause.

Takings cases are one way to ensure that the government makes those it injures whole. They are not easy to win, at least not when the idea is that property was taken by regulation (as opposed to by force). This difficulty is not a bad thing, given that the government must have some flexibility and could not go on if it had to pay for every slight differential in treatment of one class of citizens from another. The questions posed in these cases become, at some level, philosophical. Do suburbs bear unfair burdens versus cities because of federal mass transit subsidies, which redound to the benefit of the core? Or is it the other way around because of federal support for highway construction? Do the localities that support army bases do more work defending our nation than the localities that do not? Or do they benefit from disproportionate government spending?

It is impossible to balance these interests merely by referencing Penn Central Transportation Co. $v$. City of New York ${ }^{193}$ and pondering the character of the governmental action, its economic impact, and its interference with reasonable investment-backed expectations. Such takings cases can only be understood by experience, not logic. ${ }^{194}$ And the experience of plaintiffs in takings cases involving bank regulation is not a particularly happy one.

192 Evan J. Criddle, Fiduciary Foundations of Administrative Law, 54 UCLA L. REV. $117,122(2006)$.

193 Penn Cent. Transp. Co. v. City of New York, 438 U.S. 104 (1978).

194 Oliver Wendell Holmes Jr. expressed the opposite view, famously claiming that "the 
One of us would be receptive to a change in this regard. Takings cases exemplify the advantages of ex post review, which may explain why they went further than almost every other case filed to contest the executive branch's administration of the response to the financial crisis. ${ }^{195}$

This sort of long-dated review of government excess, moreover, is best suited if the sanctions involved are monetary damages, rather than injunctions aimed at long-past administrative action. These are the sorts of causes of action that could permit the courts to review the government at some point, without necessarily limiting the government's emergency freedom of action in the depths of a difficult situation.

But without such a doctrinal shift by the courts, takings cases are difficult to bring and difficult to win. Indeed, the lead plaintiff among the Fannie and Freddie shareholders, the hedge fund that brought the initial case, eschewed the Takings Clause entirely.

The plaintiffs instead pursued a claim under the APA, and there is good reason to turn to that statute when other legal remedies against the government look unavailing. Falling within William Eskridge and John Ferejohn's definition of a "super-statute," the APA has developed an arguably subconstitutional status as a baseline law that provides rights that are both fundamental and unlikely to be revisited. ${ }^{196}$ Super-statutes develop from a "lengthy period of public discussion and official deliberation," and establish principles, such as the general reviewability of agency action, that are "foundational or axiomatic to our thinking" and have "passe[d] the test of time." 197 They are concise and rarely amended, and therefore depend upon judicial interpretation and enlargement. The APA has these features. ${ }^{198}$

life of the law has not been logic: it has been experience." O. W. HOLMES, JR., THE COMMON LAW 1 (1881).

${ }^{195}$ David Zaring, Litigating the Financial Crisis, 100 VA. L. REV. (forthcoming 2015) (considering the resort to takings in the wake of the financial crisis).

196 William N. Eskridge, Jr. \& John Ferejohn, Super-Statutes, 50 DUKE L.J. 1215, 1216 (2001) ("A super-statute is a law or series of laws that (1) seeks to establish a new normative or institutional framework for state policy and (2) over time does 'stick' in the public culture such that (3) the super-statute and its institutional or normative principles have a broad effect on the law.").

${ }^{197} I d$. at 1231,1273 . As Eskridge has said, "[t]he framework for understanding most national lawmaking and much federal adjudication in this country is no longer Article I, Section 7 or Article III of the Constitution, but is instead the Administrative Procedure Act of 1946." William N. Eskridge, Jr., America's Statutory "Constitution," 41 U.C. DAVIS L. REV. 1, 12 (2007).

198 Justice Scalia observed in 1978 that "the Supreme Court regarded the APA as a sort of superstatute, or subconstitution, in the field of administrative process: a basic framework that was not lightly to be supplanted or embellished." Antonin Scalia, Vermont Yankee: The APA, the D.C. Circuit, and the Supreme Court, 1978 SUP. CT. REV. 345, 363 (1978). For a discussion of the prospect of including the APA among the category of super-statutes, see Kathryn E. Kovacs, Leveling the Deference Playing Field, 90 OR. L. REV. 583, 606-08 
The APA is, it is fair to say, the broadest waiver of sovereign immunity the federal government has made since Marbury $v$. Madison. ${ }^{199}$ And the standard of review it applies to government action - an arbitrary or capricious standard that tests the regulatory efforts of agencies to ensure that they stay within the outer bounds of reasonableness-is a broadly familiar metric, that, when not overly complicated with judicial review doctrine, provides a coherent, measurable means to evaluate what the government is trying to do. ${ }^{200}$

The APA accordingly pairs well with a claim premised on another classical form of injunctive relief, that is, injunctive relief for shareholders attacking the operation of corporations by fiduciaries responsible to them. The APA's premise of reviewability, at least under its lenient standards, provides a plausible, doctrinally justified work-around to an otherwise demanding exercise in sovereign immunity. Finally it is generally perceived as the right vehicle to review idiosyncratic government action, such as the rare case in which the government operates a firm. ${ }^{201}$ There is little basis to believe that share ownership is something so strange as to be beyond the ken of the statute, which generally strives to encompass most forms of regulatory action. ${ }^{202}$

\section{(2011).}

199 Under Marbury, it is the role of the court "to say what the law is," Marbury v. Madison, 5 U.S. (1 Cranch) 137, 177 (1803), while the APA provides that "the reviewing court shall decide all relevant questions of law," 5 U.S.C. $§ 706$ (2014). Eric Braun observed that the grant of judicial review amounted to the "unique law-declaring role of the courts enunciated in Marbury v. Madison, and the command of the APA that the 'reviewing court shall decide all relevant questions of law." Eric M. Braun, Note, Coring the Seedless Grape: A Reinterpretation of Chevron U.S.A. Inc. v. NRDC, 87 COLUM. L. REv. 986, 988 (1987) (citation omitted).

${ }^{200}$ See Zaring, supra note 111 , at 155 (arguing that a reasonableness standard best captures the sort of review required by the APA):

201 As Ed Rock and Marcel Kahan have observed,

When the government becomes a controlling shareholder of a private firm, we face an inverted set of these issues. Government involvement, as we will see, changes everything. It immediately raises issues of sovereign immunity and its various and sundry waivers. It forces corporate law scholars to venture into the realms of Administrative Law - the content of ... the APA.

Kahan \& Rock, supra note 82, at 1297.

${ }^{202}$ See 5 U.S.C. $\S \S 103(1), 105$ (2012) (providing that "Executive agency" includes a corporation "owned or controlled by the Government of the United States"); id. § 552(f) (2012) (applying public records provision to "Government controlled corporations" as well as "Govemment corporations"). For a discussion of government corporations and the APA, see A. Michael Froomkin, Reinventing the Government Corporation, 1995 U. ILL. L. REV. $543,623,632-34$. To be sure, some government corporations have been exempted from some of the requirements of administrative procedure. As Anne O'Connell has observed, "in a recent survey of government corporations, the [Government Accountability Office] had to rely on self-reports to determine which of fifteen statutes (including the APA and FOIA, among others) applied to each respondent." Anne Joseph O'Connell, Bureaucracy at the Boundary, 162 U. PA. L. REv. 841, 896 (2014). 
APA cases have often been brought over agreements between two government agencies such as the agreement between FHFA and Treasury in this case. ${ }^{203}$ Indeed, the seminal case on standing law, Lujan $v$. Defenders of Wildlife, ${ }^{204}$ which established the test for when plaintiffs had suffered a sufficient injury both caused by, and redressable by, the government, involved a recommendation by the Fish and Wildlife Service to the State Department. ${ }^{205}$ Because of its injunctive component, the APA also gives the sense that justice sometimes must be done, and in this case, the government has never tried to argue that the just choice would be to find against the holders of the preferred stock, which would be gazumped by the Third Amendment.

None of this means that the statute is a foolproof vindicator of our rights and freedoms against all forms of governmental overreaching, but it does suggest that the APA can fairly be viewed as a catch-all statute of last resort. The APA is a vehicle for claims to be made when alternatives do not exist and when the prospect of no claim being possible looks tremendously unfair. ${ }^{206}$ Courts can, in these cases, stretch to make creative claims-and even, at times, creative remedies-cognizable.

\section{B. The Administrative Remedy Applied to Fannie Mae and Freddie Mac}

The question is: What does the application of entire fairness mean for Fannie Mae and Freddie Mac? In essence this involves the question of the details of the entire fairness analysis. As discussed above, an entire faimess analysis involves a test for "fair price" and "fair procedure." However, in administrative review, the concept of arms-length bargaining is foreign. There is no arms-length bargaining with the government. Instead, fair process is the process due to someone under the attributes of administrative law. This

${ }^{203}$ See, e.g., Snepp v. United States, 444 U.S. 507, 510, 515-16 (1980) (per curiam) (upholding the CIA's secrecy agreement with its former agent because of the "extremely high degree of trust" between agent and agency).

204504 U.S. 555 (1992)

${ }^{205}$ See id. at 558 ("In 1978, the Fish and Wildlife Service (FWS) and the National Marine Fisheries Service (NMFS), on behalf of the Secretary of the Interior and the Secretary of Commerce respectively, promulgated a joint regulation."). The standing test announced in Lujan requires that, "First, the plaintiff must have suffered an 'injury in fact'-an invasion of a legally protected interest which is (a) concrete and particularized, and (b) 'actual or imminent, not "conjectural" or "hypothetical."' Second, there must be a causal connection between the injury and the conduct complained of - the injury has to be 'fairly ... trace[able] to the challenged action of the defendant, and not ... th[e] result [of] the independent action of some third party not before the court.' Third, it must be 'likely,' as opposed to merely 'speculative,' that the injury will be 'redressed by a favorable decision."' Id. at 560-61 (citations omitted).

206 Partly for this reason, "[t]he vast majority of the [federal government corporations] are subject to the APA." Marshall J. Breger \& Gary J. Edles, Established by Practice: The Theory and Operation of Independent Federal Agencies, 52 ADMIN. L. REV. 1111, 1229 n.616 (2000). 
reduces the analysis to one of what that price would be. In other words, what would be the price that Fannie or Freddie would have to pay to purchase the remaining stub at this time? ${ }^{207}$

In the case of Fannie and Freddie's common stock, the market value is a good guide. Fannie began the month of August 2012 trading at $\$ 0.23$ per share and finished that month at $\$ 0.25$ per share. ${ }^{208}$ Freddie began the month of August 2012 trading at $\$ 0.23$ per share and ended the month trading at $\$ 0.24$ per share. ${ }^{209}$ In other words, the market was valuing the stub equity of Fannie and Freddie at between $\$ 0.25$ and $\$ 0.23$, per share, respectively.

As for the preferred stock, it too had a value in the market at the time. For example, Fannie Mae's Preferred Series E stock began the month at $\$ 1.40$ per share but went down to $\$ 0.42$ per share by the end of the month. ${ }^{210}$ Simultaneously, Freddie Mac's Preferred Series Z stock started the month at $\$ 1.98$ per share and finished the month at $\$ 0.93$ per share. ${ }^{211}$

We believe that in this case, stock prices along with a valuation analysis typical of entire fairness should determine the value taken from shareholders by the Third Amendment. This analysis would involve financial experts using the tools of their trade to value Fannie Mae and Freddie Mac. The basic tool would be a discounted cash flow analysis, as there really are no comparable companies to Fannie Mae and Freddie Mac. Of course, such a discounted cash flow analysis would need to forecast the future profits (and cash flows) of the two GSEs. This essentially devolves into an assessment of the housing market's prospects at the time of the Third Amendment and the competitive position of Fannie Mae and Freddie Mac. With regard to the latter, the two GSEs had come to not only dominate, but also comprise the entirety of, the

207 This is in essence another straightforward application of entire fairness review as the Delaware courts have done in other contexts. See In re John Q. Hammons Hotels Inc. Shareholder Litig., Civil Action No. 758-CC, 2011 WL 227634, at *3-4 (Del. Ch. Jan. 14, 2011) (explaining that the fair price prong of an entire faimess analysis is established by first examining the methodologies the parties used to value the company and then determining the fair value of the company).

208 Federal National Mortgage Association (FNMA): Historical Prices, YAHOO! FINANCE,

http://finance.yahoo.com/q/hp?s=FNMA\&a=07\&b=1\&c=2012\&d=07\&e=31\&f=2012\&g=d (last visited Nov. 4, 2014).

${ }^{209}$ Federal Home Loan Mortgage Corporation (FMCC): Historical Prices, YAHOO! FINANCE,

http://finance.yahoo.com/q/hp?s=FMCC\&a=07\&b=1\&c=2012\&d=07\&e=31\&f=2012\&g=d (last visited Nov. 4, 2014).

210 Federal National Mortgage Association (FNMFM): Historical Prices, YAHOO! FINANCE, http:/finance.yahoo.com/q/hp?s=FNMFM\&a=07\&b=1\&c=2012\&d=07\&e=31 $\& \mathrm{f}=2012 \& \mathrm{~g}=\mathrm{d}$ (last visited Nov. 4,2014 ).

211 Federal Home Loan Mortgage Corporation (FMCKJ): Historical Prices, YAHOO! FINANCE, http://finance.yahoo.com/q/hp?s=FMCKJ\&a=07\&b=1\&c=2012\&d=07\&e=31\&f $=2012 \& \mathrm{~g}=\mathrm{d}$ (last visited Nov. 4, 2014). 
market for mortgage origination at the time of the Third Amendment, a market share with tremendous value.

And what about the possibility of the housing market's recovery? Again, corporate law guides us in how entire fairness should take into account the value of Fannie and Freddie. In Delaware, "speculative" elements are not included in an entire fairness analysis. ${ }^{212}$ Instead, "elements of future value ... which are known or susceptible of proof as of the date of the merger and not the product of speculation, may be considered [in determining fair value].'213 In this case the court was referring to a merger, but the Third Amendment can be substituted here.

In internal documents, the government justified the Third Amendment by an analysis which found that the companies would be unable to pay the ten percent dividend, effectively making them insolvent. ${ }^{214}$ However, the analysis assumed that the GSEs would be unable to pay the dividend because of a government wind-down. Again, this claim would be assessed as of 2012, and the question would be whether the government's prediction of a wind-down was speculative at the time.

The end result is that, while there will be a battle of the experts, it appears that there should be some recovery for the shareholders. While stock prices are not the determinative factor in entire fairness proceedings, in this case, they may be a good market approximation of the prospects of such a massive recovery (which did in fact occur). Certainly, it would be appropriate under corporate law to consider these prices, informed by traditional valuation analysis. ${ }^{215}$ In any event, under our analysis, that recovery is likely limited and likely less than the billions of dollars in value the stock is currently being traded at.

\section{LESSONS FOR THE NEXT FINANCIAL CRISIS}

One way of scaling the concerns posed by the sorts of interventions that the government took with regard to Fannie and Freddie is to consider them in

212 Weinberger v. UOP, Inc., 457 A.2d 701 (Del. Super. Ct. 1983).

213 Id. at 713.

214 See Treasury Defendants' Memorandum in Support of Their Motion to Dismiss, or in the Alternative, for Summary Judgment at 49-55, In re Fannie Mae/Freddie Mac Sénior Preferred Stock Purchase Agreement Class Action Litigs. (D.D.C. 2014) (No. 1:13-cv19250RLW), available at http:/go.bloomberg.com/assets/content/uploads/sites/2/2014/ 02/Perry-v-Lew-MTD.pdf; Pershing Square Complaint, supra note 2, at 197 72-74; see also Matt Levine, Hedge Fund Billionaire Thinks Fannie Mae Should Be Working for Him, BLOOMBERGVIEw (Aug. 15, 2014, 6:05 PM), http://www.bloombergview.com/articles/201408-15/hedge-fund-billionaire-thinks-fannie-mae-should-be-working-for-him, archived at http://perma.cc/B4WB-SFHH (discussing the analysis and concluding that the government's position was "really not very plausible at all").

215 See Weinberger, 457 A.2d at 713 (broadening the concept of "fair price" to include factors such as market value). 
relation to the alternatives that the government might take in the wake of a similar emergency. Many of the actions the government might take should pass judicial scrutiny; it is only when the sorts of seizures involved in Fannie and Freddie come to pass that we should expect judicial scrutiny to be more searching-and even then, the likelihood of a windfall is small. A second useful exercise is to develop a theory of what, exactly, should be the remedy for property seizures in emergency contexts, given that they are likely to recur so long as regulation by deal remains a part of the government's toolkit.

\section{A. Implications for Government Dealmaking}

Despite its seemingly awesome flexibility in financial crises, the government is and was legally constrained during the most recent crisis. In some ways, those legal constraints drove the government's decision to handle much of the crisis response through dealmaking. ${ }^{216}$ Dealmaking offered a way around some of the legal constraints posed by administrative procedure and due process. The agencies that were dealmakers were those with the flexible statutory authorizations and balance sheets necessary to mount a rescue-and, if necessary, a takeover - of financial institutions like Fannie Mae and Freddie Mac. $^{217}$

The way Treasury treated Fannie and Freddie shows how important legal constraints can be. Treasury and FHFA took over Fannie and Freddie only because they had recently received the authority to do so from HERA; that authorization defined how the takeover was structured. ${ }^{218}$ Without it, it is not clear how the government would have gone about the process of rescuing the two institutions-but it might have looked different indeed.

The case that the preferred and common shareholders have brought against Fannie and Freddie is an example of the aftermath of regulation by deal. When the government uses its emergency powers in dramatic and unforeseen ways it is likely that the consequences will be unpredictable. The way that Treasury and FHFA managed the injection of capital into the two GSEs was quick and unprecedented, although not unauthorized by statute. ${ }^{219}$ Quick and

${ }^{216}$ See generally Davidoff \& Zaring, supra note 9 (explaining how the government's influx of capital into companies pushed the legal boundaries of administrative law).

${ }^{217} \mathrm{Id}$. at 465-66 (explaining how regulators with greater resources and legal flexibility exceeded their designated jurisdictions during the crisis, while other agencies and regulators stood pat).

218 See Housing and Economic Recovery Act of 2008, Pub. L. No. 110-289, 122 Stat. 2654 (codified at 12 U.S.C. $\S \S 4501-4602$ (2012)) $\S 1313$ (permitting the Director to "[r]equire the regulated entity to take any other action that the Director determines will better carry out the purposes of this section").

219 See id. $\$ 1111$ ("The Director may, at any time by order or regulation, establish such capital or reserve requirements with respect to any product or activity of a regulated entity, as the Director considers appropriate to ensure that the regulated entity operates in a safe and sound manner, with sufficient capital and reserves to support the risks that arise in the operations and management of the regulated entity."). 
unprecedented dramatic actions are likely to have unpredictable consequences; the fallout over the Fannie and Freddie takeovers was spurred by the way the government only partly nationalized the companies. Sometimes-and this is particularly the case when the government rescues the financial sectorregulation by deal is inevitable and should not be punished too harshly. What we seek to do in this Article is illustrate that government dealmaking has consequences and is a form of regulation to which the government is not particularly accustomed.

In order to limit these consequences, we propose that when regulation by deal occurs, it has a time limit. On a technical scale, a foreclosing rule will also likely lead to more beneficial deal-structuring by government in these situations. In part the Dodd-Frank Act is an attempt to legislate for such an outcome. However, as we have both written elsewhere, the Dodd-Frank insolvency apparatus for "too big to fail" institutions is unlikely to ever be utilized. ${ }^{220}$ Regulation by deal is likely to persist, even within the Dodd-Frank apparatus, as legislators attempt to craft bespoke solutions around rigid legal rules in a time of crisis.

When government rescues occur, the foreclosing rule that we suggest here is apt to lead to cleaner economic outcomes for the government and for other stakeholders by creating more definitive solutions at the time of the crisis. The key would be to nudge, if not push, government officials doing deals to think more like dealmakers and to structure transactions with the future, as well as the present-day problems, in mind. This may confine regulation by deal to those cases where it is optimally necessary, and when it is used, to be implemented in a manner that is designed for an end date.

A limitation of this nature is likely to lead to better economic outcomes. The temptation to use the unleashed, brute force of government at the time of crisis will be tempered by the knowledge and specter of foreclosing action. While this will likely not lead to perfect outcomes - the sine qua non of regulation by deal-it will push regulators towards better structuring decisions. Nor do we think this is too much to ask even in the heat of the crisis. After all, the government's negotiators were sophisticated transactional attorneys. They specialized in structuring transactions like these, in short time periods, to be preserved for a significant duration.

Moreover, as a policy and legal matter, courts should reassert legal authority once the financial crisis fades. In the depths of the financial crisis, laws are bent and courts look on by the wayside. ${ }^{221}$ While we recognize that the legal

${ }^{220}$ David Zaring, A Lack of Resolution, 60 EMORY L.J. 97, 156-57 (2010) ("This sort of power-too much resolution authority-is daunting for regulated banks and thrifts, and if applied to a broader, less well-defined set of institutions, could scare a broad swath of investors."); Steven Davidoff Solomon, The Too Big to Fail Quandary, N.Y. TIMES DEALBOOK (Feb. 22, 2011, 2:47 PM), http://dealbook.nytimes.com/2011/02/22/a-quandaryover-deeming-behemoths-too-big-to-fail/?pagemode=print\&_r=1.

${ }^{221}$ The Delaware courts, for example, refused to interfere in the government's bailout of 
rule-bending that accompanied regulation by deal during the financial crisis may be necessary, it also should have an expiration date, if for no other reason than to reestablish the values of due process and the integrity of law. We do not think that these are reasons to prevent the government from trying to stabilize markets in the event of a financial crisis. We do think that there must be some discipline. The government should not simply resort to regulation by deal because other regulatory alternatives are more constraining and the dealmaking is attractively unfettered. This explains our measured sympathy for the plaintiffs in this case, and our offer of a way to discipline the government without shackling it within the laws as they exist today.

\section{B. On the Virtues of Shareholder Activism}

This sort of lawsuit, if taken seriously, gives voice to activist shareholders, even though the activist shareholders being vindicated are rather unsympathetic hedge funds. That may be a praiseworthy development, and it certainly is a novel one in administrative law. Corporate law scholars, of course, are very familiar with the phenomenon of discipline through shareholder activity. Indeed, a number of corporate law scholars have written in praise of the activist shareholder as a mechanism for disciplining management; Lucian Bebchuk is particularly associated with this view. ${ }^{22}$ This does not mean, of course, that these shareholders always act for good, and just as some have praised the advent of activist shareholders, others have been quick to point out their flaws. ${ }^{223}$

But engagement with activist shareholders, as opposed to just plain activism, is something new for regulators. Their understanding of the impositions of activism used to be a matter of coming to terms with Washington-based non-governmental organizations like the NRDC and the Community Nutrition Institute.

Activist shareholders are different, and may motivate regulatory policy in a way unlike those organizations. They have "skin in the game" in that they have invested in the hope of a particular government policy. The government is not often likely to be a controlling shareholder or manager of an enterprise with such shareholders (though it may end up with precisely these sorts of stakes in the aftermath of future economic crises), but it is encountering activism from those with minority stakes in other companies. These activists may seek

Bear Stearns despite significant legal issues. See Marcel Kahan \& Edward Rock, How to Prevent Hard Cases from Making Bad Law: Bear Stearns, Delaware, and the Strategic Use of Comity, 58 EMORY L.J. 713, 756 (2009).

222 See, e.g., Lucian Arye Bebchuk, The Case for Increasing Shareholder Power, 118 HARV. L. REV. 833, 838-39 (2005) (arguing that boards of directors pay insufficient heed to shareholder interests); Lucian A. Bebchuk, The Myth of the Shareholder Franchise, 93 VA. L. REV. 675, 694-711 (2007) (suggesting reforms designed to encourage greater shareholder participation in the election of directors).

${ }^{223}$ See, e.g., L yNN StOUT, THE Shareholder Value MYTH 2-10 (2012). 
favorable regulatory treatment, as have investors who have purchased failed banks from government receivers in the past, ${ }^{224}$ or they may seek federal investigations of firms in which they hold a short position. ${ }^{225}$

We believe that the new prominence of activist investors in matters of regulatory policy is a development worth scrutinizing, and we predict that it will continue in the future. In particular, privatization of government services is a perpetual idea. In between these alternatives is the less visible publicprivate-hybrid corporation that the GSEs represent. Despite concerns about shareholder activism in corporate America, the presence of a vibrant shareholder activist force may be a compelling push towards the creation of more of these types of entities, functioning as a disciplinary mechanism and a way to harness both the private goods of the public sector and the public goods of the government. At a minimum, we believe that the promise of these types of entities in the current capital markets is worth significant study.

\section{A Problem of Over-Deterrence?}

One other concern that might be raised by our approach lies in the risk of over-deterrence of government rescues. Would the remedy we propose slow the government's interventions in the financial sector when quick action is needed?

We are unworried. The Fannie and Freddie seizures were dramatic, if not unprecedented. But critically, the government has continued to operate these businesses. At some point, the allowances made for crisis action must give way to the aftermath and the reassertion of a stronger form of law. Regulation by deal should not be without consequences.

The government can-and has-intervened in the economy to save financial institutions in a variety of ways. A takeover is the most dramatic option; it impacts the owners and, usually, the managers of the banks most severely. It also has a hint of unexpectedness about it. In this country, state-owned enterprises are few; a state-owned enterprise created as a response to a crisis is even more inconsistent with the ordinary hostility of the country towards governmental capitalism. ${ }^{226}$

${ }^{224}$ See supra notes 172-178 and accompanying text (describing the Winstar litigation, which featured plaintiffs who made such arguments).

${ }^{225}$ For example, the investor William Ackman has urged the government to investigate a diet supplement company that engages in multilevel marketing as a practitioner of deceptive trade practices. See Beth Jinks et al., Herbalife Brings Bill Ackman Back to Where He Began, BLOOMBERG (July 22, 2014, 8:50 PM), http://www.bloomberg.com/news/2014-0723/herbalife-bashing-brings-bill-ackman-behind-where-he-first-began.html, archived at https://perma.cc/63AW-2XF7?type=source; see also Pershing Square Capital Mgmt., L.P., FACTS ABOUT HERBALIFE, http://www.factsaboutherbalife.com, archived at http://perma.cc/H9VT-TYNZ (last visited Nov. 11, 2014) (publicizing the claims of Ackman's hedge fund concerning the diet supplement company and urging a federal investigation).

226 However, to be sure, there are more government corporations around than one might 
In such cases, where minority shareholders bear particular burdens, it makes sense to compensate them not with a windfall, but with compensation for the value of their destroyed property. Doing so encourages wise government interventions; we do not believe it would deter them.

The sanction we think appropriate here is proportional to the strong action taken. The severity of the imposition against the minority shareholders marks this as a corporate management case that is different from the various ways that the government generally can intervene to protect the financial system. A smidgen of deterrence here would do nothing to limit the government's ability to stabilize banks by acting as a lender of last resort to them, which the nineteenth-century finance theorist Walter Bagehot thought was the best practice for a financial system intervention. 227 It does nothing to affect the other tools the government has, including regulatory forbearance and macroprudential efforts to use monetary policy or an economic stimulus to stabilize financial institutions.

We therefore do not see our approach as something that would prevent the government from regulating, even regulating freely, and, indeed, even regulating by deal in this space. It would not, however, be able to do so costlessly or without end.

\section{CONCLUSION}

The government's actions with regard to the shareholders of Fannie and Freddie should be put in perspective; we do not think that awarding a limited remedy to the shareholders in this case means that takings or administrative law claims will be due to all those variously burdened by other forms of financial rescue. There are reasons to think carefully through what kind of discipline the government should face when it engages in regulation by deal. But if the government, in the course of its dealmaking, is to take over and manage a business enterprise, then it should be subject to the same sorts of

think, ranging from the post office to Intelsat. See O'Connell, supra note 202, at 851 ("The variety, number, and importance of these organizations greatly complicate the classic image of the federal administrative state-that of a bureaucracy consisting almost entirely of executive agencies and independent regulatory commissions.").

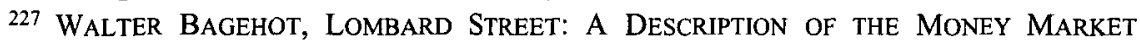
VII.57, available at $\mathrm{http}: / / \mathrm{www}$.econlib.org/library/Bagehot/bagLom7.html. In emergencies, it would be the lender of last resort-the last place a bank could go when faced with a liquidity problem to obtain short-term financing to ride that problem out. See id. at 196 ("Nothing . . . can be more certain than that the [central bank] . . . in time of panic . . . must advance freely and vigorously to the public out of the reserve."). Bagehot also introduced two limitations on the lender of last resort role: "First[,] . . these loans should only be made at a very high rate of interest," and "Second[,] . . at this rate the advances should be made on all good banking securities, and as largely as the public ask for them." Id. at 197-98. For a discussion of the applicability of Bagehot's dictums today, see Andrew W. Hartlage, Europe's Failure to Prepare for the Next Financial Crisis Affects Us All, 44 GEO. J. INT'L L. $847,857-58$ (2013). 
duties we expect of the managers of private business enterprises. Those managers are, of course, protected by the business judgment rule. They enjoy broad discretion in deciding what sort of business they would like to engage in, and whether and how much they wish to devote resources to corporate social responsibility, let alone other broader welfare programs and political imperatives.

Discretion does not, however, permit shareholder oppression or a breach of the fiduciary duties to which the government has committed itself by taking its stake in Fannie Mae and Freddie Mac. In cases where, as here, the government has taken over corporations that have previously been observing the niceties of state corporate law, at some point-perhaps not in the depth of a crisis, but as its ownership stake matures-it should be required to observe those niceties as well.

In this way, administrative law, which is ordinarily used to discipline government action in cases like this, can usefully look to the basics of corporate law for a doctrinal understanding of what arbitrariness means - and a remedy as well.

Subjecting the government to an entire fairness analysis as it continues to pursue its policy objectives through a government takeover and subsequent management of a putatively private corporation is the right way to afford the government flexibility without subjecting it to harsh penalties for action forged in the midst of a complex and alarming financial crisis. It is also a natural outcome of the current, existing law on these issues.

Financial crises are likely to reoccur, and the government is likely to respond to those crises through dealmaking. On these occasions, some will be hurt by the government's rescues. While the government must have some discretion to handle emergencies in the way it wishes, emergencies are not free passes from the law. Because the government must be permitted to act in a crisis, it must also face a limit upon the window in which it might act without constraints. There must be constraints on the government's action while that window is closed, and even to some extent while it is still open. Our Article provides a way forward, showing how those constraints might be implemented. An ancillary benefit is that our approach might push the government to use more foresight when it does act through regulation by deal.

The Fannie and Freddie lawsuit, if taken seriously, also gives voice to activist shareholders. We believe that this may be a good and significant development. It may be that the market-based regulation that many have advocated for finally finds its first fruit in the battle over Fannie Mae and Freddie Mac and the involvement of these activist hedge funds. And, perhaps in this vein, the idea of a quasi-private governmental corporation is ripe for further exploration for solving the public-private dilemma.

The resolution of Fannie Mae and Freddie Mac, which remains open at the time of our writing, is thus not just about the two GSEs, the financial crisis, and the end date for regulation by deal. It is also about the intersection of corporate and administrative law, as well as the age-old conflict between 
manager and shareholder. Previous scholarship has observed this intersection and dismissed the corporate law aspect. But just as corporate law issues pervaded and drove the government's financial crisis conduct, we think that corporate law also has something to say in the resolution of regulation by deal and the problem of Fannie Mae and Freddie Mac. 